\title{
Key Parameters of Measles Virus Production for Oncolytic Virotherapy
}

\author{
${ }^{1}$ Weiss, K., ${ }^{1}$ D. Salzig, ${ }^{2}$ M.D. Mühlebach, \\ ${ }^{3}$ K. Cichutek, ${ }^{4} \mathrm{R}$. Pörtner and ${ }^{1,5,6} \mathrm{P}$. Czermak \\ ${ }^{1}$ Institute of Bioprocess Engineering and Pharmaceutical Technology, \\ Mittelhessen University of Applied Sciences, Giessen, Germany \\ ${ }^{2}$ Oncolytic Measles Viruses and Vectored Vaccines, Paul-Ehrlich-Institut, Langen, Germany \\ ${ }^{3}$ Divsion of Medical Biotechnology, Paul-Ehrlich-Institut, Langen, Germany \\ ${ }^{4}$ Hamburg University of Technology, Hamburg, Germany \\ ${ }^{5}$ Department of Chemical Engineering, Kansas State University, Manhattan KS, USA \\ ${ }^{6}$ Faculty of Biology and Chemistry, Justus-Liebig-University of Giessen, Germany
}

Received 2012-04-23; Revised 2012-05-15; Accepted 2012-05-29

\begin{abstract}
Attenuated measles virus has revealed selective tumor cell killing and is currently tested in clinical trials for the therapy of cancer patients. The amount of infectious particles per dose needed for oncolytic therapy can be more than a million times higher compared to vaccination. This requires highly effective production processes which guarantee the measles virus quantities needed for its use in cancer therapy. Referring to measles virus production itself, several factors are influencing process parameters and subsequent virus yields. These factors are medium optimization, feeding of nutrients, an optimal multiplicity of infection, localization of produced virus particles, temperature sensitivity and time of harvest. This review summarizes the available data concerning measles virus production in cell culture and factors influencing the virus yield.
\end{abstract}

Keywords: Measles Virus (MV), Subacute Sclerosing Panencephalitis (SSPE), Major Complement Protein (MCP), Cytopathic Effect (CPE)

\section{INTRODUCTION}

Measles is a highly infectious disease of the respiratory and lymphoid systems caused by Measles Virus (MV). Beside the typical rash and Koplik spots, this disease is clinically characterized by high fever and a considerably weakened state of health due to transient, distinct immune suppression. The course of disease is often relatively mild, but sometimes life-threatening. Deadly complications such as e.g., severe pneumonia or Subacute Sclerosing Panencephalitis (SSPE) occur with a fatality rate of about 1 in 1,000 patients (Sabella, 2010). Especially the life-threatening direct ethiophatology of measles can be prevented by vaccination using lifeattenuated vaccine strains of MV. These vaccines have been used in millions of doses up to now, probably evoking life-long immunity and revealing an excellent safety profile. Derivatives of these vaccine strains are used in current clinical trials for their efficacy in oncolytic virotherapy (Msaouel et al., 2011).

The only natural hosts for MV are humans or nonhuman primates. MV as a member of the order Mononegavirales is an envelope, single-stranded, negativesense RNA virus from the family Paramyxoviridae (genus Morbillivirus) (Navaratnarajah et al., 2009). The virus is found as pleomorphic particles with a size of 120-270 nm. The two glycoproteins hemagglutinin ( $\mathrm{H}$ protein) and fusion protein (F protein) are embedded in the lipid bilayer constituting the viral envelope. The matrix protein (M protein) covers the inner side of the viral envelope and modulates the activity of the viral glycoproteins (Cathomen et al., 1998). The viral RNA is encased in a ribonucleocapsid structure. The ribonucleocapsid consists of the nucleocapsid protein tightly wrapping the RNA genome and the associated viral polymerase (L) and viral Phosphoprotein (P), a cofactor of the polymerase (Fig. 1A). 


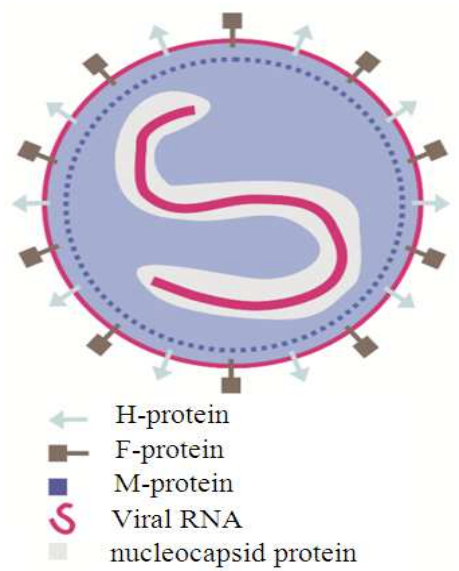

(A)

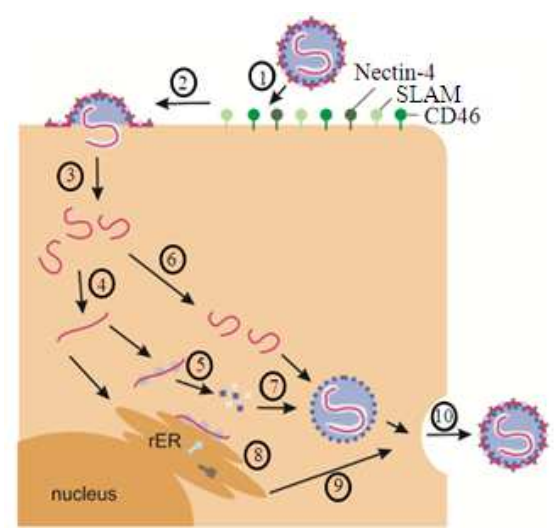

(B)

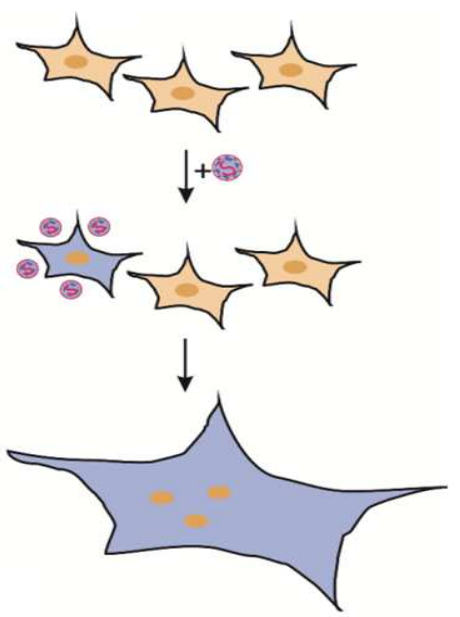

(C)

Fig. 1. Particle structure and replication cycle of MV. A: MV is a single-stranded RNA virus. Viral RNA is encapsulated by a viral nucleocapsid. The glycoproteins haemagglutinin (H protein) and fusion protein (F protein) are embedded in the lipid layer. The matrix protein (M-protein) covers the inner side of the viral envelope and interacts with viral glycoproteins and the ribonucleocapsid. B: MV attaches to the host cell membrane via the viral H protein binding to one of the three receptors SLAM, CD46, or nectin-4 (step 1). After receptor attachment, $\mathrm{H}$ is thought to trigger the associated $\mathrm{F}$ protein, resulting in fusion of viral and host cell membranes (step 2) with the formation of a fusion pore, through which the ribonucleoprotein complex enters the cells' cytoplasm (step 3). Viral RNA polymerase uses ribonucleotide triphosphates in the cytosol to transcribe the viral genome into viral mRNAs (step 4) and, after translation of viral proteins (step 5), subsequently to replicate the viral RNA genome and antigenome (step 6). Together with the replicated viral genome, the N, P and L proteins assemble a progeny ribonucleocapsid (step 7). H protein and F protein, the viral transmembrane glycoproteins, are produced at the ribosomes of the rough ER (step 8). These two proteins are transported as oligomeric complexes to the cell membrane via the Golgi apparatus utilizing the exocytotic pathway (step 9). The progeny ribonucleocapsid associates at the plasma membrane of the host cell with the viral transmembrane glycoproteins, mediated by the M protein. Direct association of the $M$ protein with the cytoplasmic domains of the $\mathrm{H}$ and $\mathrm{F}$ proteins is supposed to induce folding of the cell membrane, followed by the release of the virus particle by budding (step 10). C: Infected cells fuse with neighboring receptor-positive cells resulting in multi-nucleated giant cells (syncytia).

The attachment protein of MV, the $\mathrm{H}$ protein, exhibits no neuraminidase activity, as already indicated by its name, nor does it adsorb to neuraminic acid as entry receptor, which is otherwise typical for paramyxoviral attachment proteins of other genera (Navaratnarajah et al., 2009). The $\mathrm{H}$ and the $\mathrm{F}$ proteins mediate MV cell entry at the cell surface via fusion of the viral lipid envelope bilayer and the host cell cytoplasmic membrane (Fig. 1B). The $\mathrm{H}$ protein binds to specific host cell receptors and is thought to trigger the $\mathrm{F}$ protein via conformational changes to initiate the fusion between the virus' and the cells' membranes. Three main receptors are used by MV. Pathogenic wild-type strains of MV utilize signaling lymphocyte activation molecule (SLAM / CD150) (Tatsuo et al., 2000) on activated immune cells and nectin-4/PVRL-4 (Mühlebach et al., 2011; Noyce et al., 2011) on epithelial cells as receptors. The vaccine strain has expanded its receptor specificity and additionally uses CD46, i.e., Major Complement Protein (MCP) (Dorig et al., 1993; Gerlier et al., 1994), which is expressed on all human nucleated cells, for entry (Navaratnarajah et al., 2009). After infection, MV induces morphological changes of the cell layer, a so called Cytopathic Effect (CPE) in infected cell cultures. MV infection is accompanied by cell-to-cell fusion and formation of multi-nucleated giant cells, so called syncytia (Fig. 1C). In the late stages of MV infection, apoptosis and the lysis of the cells are induced. During the amplification phase, a considerable part of the MV particles remains cellassociated, while some particles are released from the cell membrane via budding (Morgan and Rapp, 1977).

\subsection{Application of Attenuated Measles Virus}

The initial isolation of the MV was done by Enders and Peebles (1954). The isolated strain has been derived from the throat washings of an 11 years old measles patient named David Edmonston and was therefore named Edmonston strain (Enders and Peebles, 1954). This measles virus strain was adapted to cell culture and 
attenuated by serial tissue culture passages resulting in less virulent virus strains, e.g., Edmonston B. Thus, this isolate has become the progenitor for many attenuated strains which are currently in the use for vaccination, (Fig. 2A) or research investigation.

\subsection{Use of Measles Virus For Vaccination}

It was Thomas Peebles who obtained specimens from a measles outbreak in 1954. Meanwhile, human kidney cells had been successfully cultured in vitro in the Enders lab.

In these cells, MV could be successfully cultivated for the first time and has been subsequently passaged 23 times. After inoculation of these passaged virus particles in measles-susceptible monkeys (cynomolgus monkeys), the animals developed fever, rash, viremia and anti-MV antibodies (Peebles et al., 1957). After one further passage, the cultured MV had been transferred to human amnion cell cultures and then to chicken eggs for 28 and 6 passages, respectively (Milovanovic et al., 1957). Afterwards, the virus was passaged in chicken embryo fibroblasts for 13 times. When the virus particles were then inoculated into measles-susceptible monkeys, no disease symptoms, but complement-fixing and neutralizing-antibodies were observed (Katz et al., 1958; Enders et al., 1960). These monkeys were than resistant to infection with "wild type", pathogenic MV. Based on these results a vaccine strain was developed and licensed in 1963 (Katz, 2009). Thus, measles vaccination became possible that enables control of measles epidemics.

Today, several MV strains are used and licensed for vaccination, e.g., the Moraten Vaccine (Merck) (Scheld et al., 2004) or AIK-C, Schwarz F88, CAM-70 and TD97, (Fig. 2B) (Artenstein, 2009). These vaccines have been used in millions of doses and have revealed an excellent safety profile.

Measles vaccine is currently produced by standard cell culture techniques in chicken embryo fibroblasts (Bronzino, 2000). The used process systems are mainly roller bottles or multilayer stacked plate systems (cell factories). Compared to petri dishes or T-flasks, a larger surface can be obtained with these systems.

\subsection{Potential of Measles Virus for Cancer Therapy}

Apart from vaccination, attenuated MV has a natural ability to specifically kill cancer cells. Attenuated MV enters the cell via the receptor CD46, which is frequently over-expressed on tumor cells (Davis and Fang, 2005). As MV is a lytic virus, MV replication in tumor cells leads to cell lysis of cancer cells. Intratumoral injection of the unmodified MV Edmonston strain or an Edmonston strain derived recombinant MV induced regression of large established human lymphoma xenografts in murine models (Grote et al., 2001). This oncolytic virus has also been reported to have potency against human epithelial ovarian cancer cells in vitro and in vivo, being selectively lytic for the ovarian tumor cells (Peng et al., 2002), hepatocellular carcinoma (Blechacz et al., 2006), or prostate cancer cells (Msaouel et al., 2009b), among others. Russell et al. (2010) filed a patent application which describes a method for limiting the growth of cancer cells using an attenuated MV strain. This oncolytic property qualifies MV for cancer therapy approaches and is currently examined in clinical trials with human cancer patients (Davis and Fang, 2005). Furthermore, new oncolytic MVs have been created as next generation therapeutics, which specifically target the cancer cells (Nakamura et al., 2005; Springfeld et al., 2006; Hasegawa et al., 2007; Mühlebach et al., 2010; Leber et al., 2011).

One problem of using oncolytic measles viruses for cancer treatment is the sheer amount of virus needed. Similar to virus particle based gene therapy (Nehring et al., 2004; 2006; 2009) the measles virus quantity for a therapeutic dose is three to $6 \log _{10}$ units higher than for vaccination (Msaouel et al., 2009a; 2011; Davis and Fang, 2005; Russell et al., 2010). Searching for a production process for oncolytic virus particles the question arises, whether the production process for MV vaccines cannot simply be expanded. To answer this question, the specific requirements for $\mathrm{MV}$ production are discussed in this review.

\subsection{Oncolytic MV Particles: New Aspects for MV Production}

Currently, there is just one detailed description for MV production in larger scales $(60 \mathrm{~L})$ for oncolytic therapy available, where a detailed protocol for the purification and the serum-free production with Vero cells in cell factories is presented (Langfield et al., 2011). Measles vaccines are routinely still produced using chicken embryo fibroblasts and standard cell culture techniques. While this process works for that specific purpose, it is not easily transferable for oncolytic virotherapy applications due to the up to 6 $\log _{10}$ units higher amounts of virus needed. Therefore, a massive scale up of the production process is required. All currently industrial used processes for measles vaccine production are monolayer cultures with non-uniform cell growth, limiting oxygen transport and inhomogeneous nutrient supply. From the bioprocess point of view, these processes are neither controllable, nor do they yield standardized and reproducible virus qualities and quantities. 


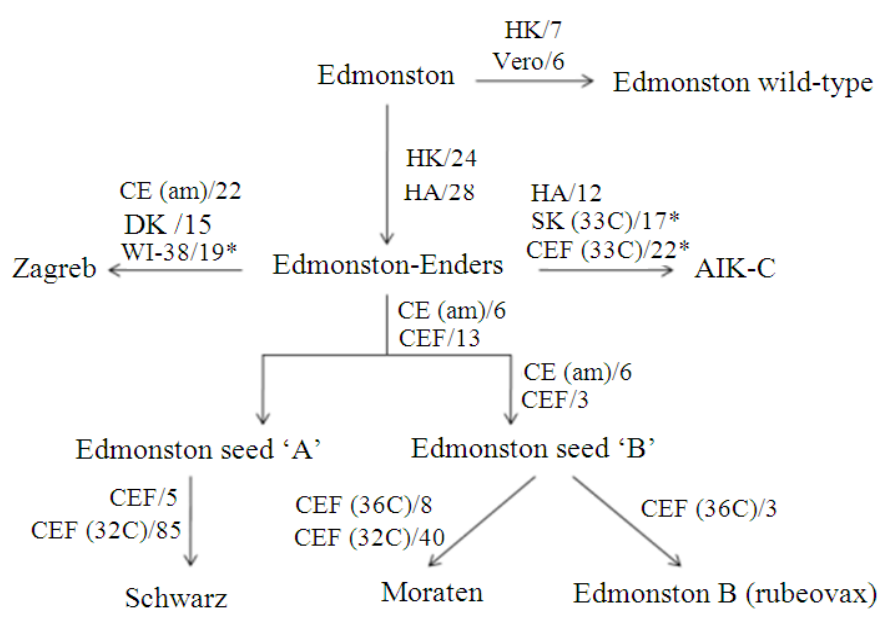

(A)
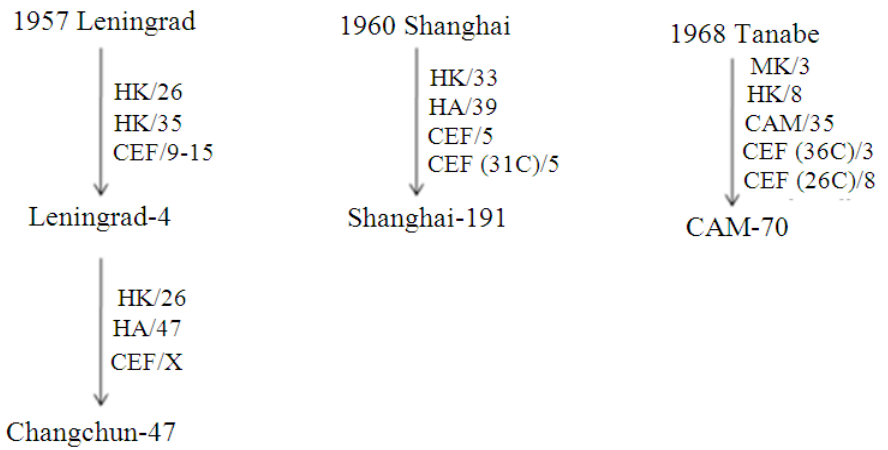

Changchun-47

(B)

Fig. 2. Histories of Edmonston derived (A) and non-Edmonston (B) derived vaccines (obtained from (Bankamp et al., 2011), with permission). Derived strains are indicated by the abbreviation of the cell culture used and the number of passages performed. The temperature was assumed to be $37^{\circ} \mathrm{C}$, other used temperatures were indicated by numbers in brackets. CAM...chorioallantoic cavity of chick embryo; CE(am)...intraamniotic cavity of chick embryo; CEF...chick embryo fibroblast; DK...dog kidney; HA...human amnion; HK...human kidney; SK...sheep kidney; WI-38...human diploid cells; *Plaque purification.

Furthermore, an efficient scale up of these processes is difficult and requires expensive robotic automations (Bronzino, 2000; Trabelsi et al., 2010). To expand these existing systems in a way that over 1 million times higher numbers of infectious particles per dose are produced, would be, even if possible, very inefficient.

Another point to consider is the virus per se, especially for those oncolytic virus particles that are fully retargeted for cancer cells. For the latter, the virus recognizes only receptors expressed on human cancer cells and propagation of these oncolytic viruses in chicken embryo cells will therefore not be possible. Thus, at least some oncolytic MV viruses have to be produced in special cells developed for this purpose, e.g. Vero-HIS cells
(Nakamura et al., 2005). For these special cells, a new process has to be established, anyway. Fermentation techniques enable high efficient production of very large volumes to provide the necessary quantity of the desired product. Production processes in bioreactors reduce overall costs and shortens time. This can easily be presented by evaluating the productivity (space-time yield), which describes the ratio of the amount of desired product, that is generated and the time and volume needed for this purpose. The productivity of conventional cultivation systems (e.g., cell factories) compared to bioreactors is supposed to be lower.

Scaling up in a bioreactor requires an increase in the reactor vessel while the operating effort stays the same. 
In contrast a scale up in a cell factory production process means increasing the number of cell factories. These additional cell factories have to be handled, which increases required material, staff costs and handling time.

Besides, bioreactor systems are characterized by its complex design and high level of instrumentation which enables online measurement and in process control with reproducibility efforts and GMP standardization. In Table 1 the main advantages and disadvantages of the two systems are compared.

The purpose of this review is to summarize published production processes for MV and factors influencing the virus yield. Moreover, it indicates starting points for further analysis to obtain sufficient amount of virus particles for oncolytic therapy. Other aspects of MV virotherapy have been reviewed already and for this reason were not covered in this review. Details covering MV biology are summarized in (Griffin and Oldstone, 2008), the current state of oncolytic trials with measles viruses is described by (Msaouel et al., 2009a, Msaouel et al., 2011). Additionally, Langfield et al. (2011) and Udem (1984) provide detailed description of methods for MV purification.

\subsection{Measles Virus Production}

Starting with the demonstration that MV could be propagated in human and simian cell cultures (Enders and Peebles, 1954), a considerable amount of data has been published on MV production. MV amplification has been described in various cell lines and with various culture modes. Parameters such as virus stability, composition of medium and virus amount have already been analyzed. Concerning an optimization of the production process, only few data have been published. The outcome in the published data was evaluated by the cell-associated and extracellular virus titers. For MV, two main methods evaluating titers of infectious MV are used. For infectivity titration, virus suspensions are diluted and endpoint dilutions are determined, at which infection is detectable (often by the appearance of syncytia) (Reed and Muench, 1938). Using statistics, virus titers are subsequently calculated as Tissue Culture Infective Dose $\left(\right.$ TCID $\left._{50}\right)$ (Kärber, 1931), which indicates the dilution of the respective virus particle suspension, at which infection is detectable in $50 \%$ of inoculated cultures. Another option of virus quantification is the evaluation of plaque formation. Employing this method, cells are infected with various virus dilutions and after an adsorption period of about two hours, a soft agar overlay containing all medium compositions is added (Mayer, 1960; Rapp, 1964). Due to the spread of the virus via cell lysis, areas of virus-induced cell destruction appear as so called plaques. The number of plaques is then counted after a defined period of time. According to this method the virus titers are given in plaque forming units (pfu). Thus, the pfu method describes an infectivity that is directly quantified, whereas the $\mathrm{TCID}_{50}$ is a statistical description of a probability of infection with $50 \%$ chance. Accordingly, a titer of $1 \times 10^{5} \mathrm{TCID}_{50} \mathrm{~mL}^{-1}$ corresponds to approximately $0.7 \times 10^{5}$ pfu mL $^{-1}$.

In the following, measles virus has been produced using serum supplemented medium, if not specified otherwise.

\subsection{Impact of Virus Strain and Cell Type for Measles Virus Production}

MV production has been analysed in several cell types and with several virus strains. Matumoto (1966) gives an overview of various cell lines, which had been analysed and could be usefull for MV production. While research groups have determined various cell types for their susceptibility to MV, industrial MV production (vaccines) are still routinely produced using chicken embryo cells (Bronzino, 2000).

Table 1. Comparison of conventional (e.g., cell factories) and bioreactor system for cell culture cultivation and production. Presentation of the main advantages and disadvantages of the respective system

\begin{tabular}{|c|c|}
\hline Conventional cultivation (e.g., cell factories) & bioreactor cultivation \\
\hline Simple design & Often more complex design \\
\hline $\begin{array}{l}\text { Low level of instrumentation, but requires transport } \\
\text { of the whole culture to e.g., work bench for medium } \\
\text { exchange }\end{array}$ & $\begin{array}{l}\text { Requires external equipment (e.g., heating } \\
\text { circuit, sterile couplers) }\end{array}$ \\
\hline Low level of control (limitation of metabolites) & $\begin{array}{l}\text { Possibility of direct regulation for appropriate } \\
\text { physical and chemical requirements }\end{array}$ \\
\hline $\begin{array}{l}\text { Due to static cultivation development of local } \\
\text { concentration gradients }\end{array}$ & Increased homogeneity \\
\hline $\begin{array}{l}\text { Due to increased inhomogeneity reduced } \\
\text { stability and reproducibility }\end{array}$ & Increased stability and reproducibility \\
\hline Ease of handling in small scale & Easier to handle in larger scales \\
\hline $\begin{array}{l}\text { During cultivation measurement of parameters } \\
\text { hard to perform }\end{array}$ & $\begin{array}{l}\text { Online monitoring of process parameters with } \\
\text { integrated sensor }\end{array}$ \\
\hline Insufficient oxygen supply for high cell densities & Increased oxygen transfer into the medium \\
\hline
\end{tabular}




\subsection{The Edmonston Strain}

As already mentioned, the Edmonston strain is up to now the most commonly used strain for vaccine development. The maximum virus yield obtained with the Edmonston strain has been determined by different groups, while various cell lines were infected with this MV strain (Black, 1959; Kohn and Yassky, 1962; Nakai et al., 1969; Romano and Scarlata, 1973; Baczko and Lazzarini, 1979; Brandriss et al., 1982; Scott and Choppin, 1982; Mendonca et al., 1994; 2002) (Table 2).

Black (1959) gained a maximum titer of $6.3 \times 10^{5}$ pfu $\mathrm{mL}^{-1}$ with Hep-2 cells, whereas Romano and Scarlata (1973) described a maximum titer of $4.6 \times 10^{4}$ $\mathrm{TCID}_{50} \mathrm{~mL}^{-1}$ in HeLa cells and Udem (1984) a maximum of $1 \times 10^{8} \mathrm{pfu} / \mathrm{mL}$ in HeLa cells. In KB cells, a maximum titer of $5.6 \times 10^{6} \mathrm{TCID}_{50} \mathrm{~mL}^{-1}$ was obtained (Kohn and Yassky, 1962). A maximum value of $1 \times 10^{7}$ pfu $\mathrm{mL}^{-1}$ was produced with BSC-1 cells (Nakai et al., 1969), whereas MV produced in Vero cells had a maximum titer of $1.7 \times 10^{8} \mathrm{TCID}_{50} \mathrm{~mL}^{-1}$ (Mendonca et al., 1994; 2002). MV production in the suspension cell line $\mathrm{U} 937$ resulted in a titer of $6 \times 10^{6} \mathrm{pfu} \mathrm{mL}^{-1}$ (Brandriss et al., 1982). A comparison of Vero, BGMK, CV-1, Hep-2, AV 3 , BHK-21, PK-15 and MDCK cells infected with the Edmonston strain revealed that Vero and BGMK cells produced the highest virus yields (Scott and Choppin, 1982). The yield with Vero cells was slightly higher with a maximum value of $2.8 \times 10^{8} \mathrm{pfu} \mathrm{mL}^{-1}$. Other cell lines had reduced virus production, with 7-28,000 times lower titres. MDCK cells had the lowest production rate with just $1 \times 10^{4}$ pfu $\mathrm{mL}^{-1}$ (Scott and Choppin, 1982).

A further analysis of MV production in Vero and MA160 cell monolayers as well as MA160 cells cultured in suspension has been published. A maximum titer of approx. 30 pfu per cell was described on MA160 monolayers, while the titers in Vero cells were approximately three times lower. In contrast, with suspension culture of MA160 cells, a yield of 100-800 pfu per cell (equals $2 \times 10^{7}-1.6 \times 10^{8}$ pfu mL $\mathrm{m}^{-1}$ ) could be reached; this is an increase of 20-100 times compared to the monolayer titers. However, besides the parameters cell types and culture mode, the medium supplements have also been varied during the three culture set-ups (Baczko and Lazzarini, 1979). Thus, no absolute comparison is feasible, since the impact of medium composition on MV production yields has already been documented, as well (Romano and Scarlata, 1973; Scott and Choppin, 1982). Taken together, these data may be helpful for choosing an optimal MV producer cell line, but have to be interpreted with respect to the composition of the medium.

\subsection{Other Measles Virus Strains}

Besides the Edmonston lineage, several other strains of MV have also been examined. These are the Hallé strain (Dubois-Dalcq and Reese, 1975; Scott and Choppin, 1982), the TYCSA strain (a variant of the Toyoshima strain) (Shishido et al., 1967), the Leningrad16 strain (Boriskin et al., 1988; Sidorenko et al., 1989) and the AIK-C strain (Trabelsi et al., 2010) (Table 2).

Production of the Hallé strain in Vero cells was characterized by electron microscopy. Due to these data it has been suggested that infected Vero cells do not complete the first cycle of viral replication within $24 \mathrm{~h}$ after infection. At this time point, cell fusion was just starting; neither budding nor complete virus particles could be observed. In contrast, the whole monolayer appeared to be covered with syncytia after three days and viral budding could be illustrated (Dubois-Dalcq and Reese, 1975). These observations are in agreement with previous data published for MV growth curves for the Edmonston strain in other cell lines (Black, 1959; Nakai et al., 1969).

Scott and Choppin (1982) compared the virus production between the Edmonston and the Halle strains. Infection with the Edmonston strain resulted in slightly higher maximum $\mathrm{MV}$ yields compared to Hallé (approximately $1 \times 10^{8}$ vs. $2.5 \times 10^{8}$ pfu $\mathrm{mL}^{-1}$, respectively).

Vero cells infected with the TYCSA strain produced a maximum titer of $3 \times 10^{6} \mathrm{TCID}_{50} \mathrm{~mL}^{-1}$ (Shishido et al., 1967), whereas the Leningrad-16 strain amplified in quail embryo cells (Boriskin et al., 1988; Sidorenko et al., 1989), resulted in maximum titers of $1 \times 10^{7}$ or $3.6 \times 10^{5}$ TCID $_{50} \mathrm{~mL}^{-1}$ (Boriskin et al., 1988). Finally, infection of MRC-5 cells with the AIK-C strain resulted in a maximum titer of $1 \times 10^{11} \mathrm{TCID}_{50} \mathrm{~mL}^{-1}$ (Trabelsi et al., 2010). This is to our knowledge the highest titer, which has been reported for MV, yet. Table 2 summarizes maximum titers as discussed above. Direct comparison of various cell lines and measles virus strains has only been performed by (Scott and Choppin, 1982), so far, who documented the highest yields using Vero cells and the Edmonston strain. As other publications though reported higher yields with other cells and strains, the comparability of the data from different publications is not necessarily given. Especially for individual uses such as recombinant retargeted viruses for cancer therapy, investigations have to be performed with this strain anyway.

\subsection{Stability of Measles Virus}

Several parameters can influence the stability of MV particles. While some factors such as temperature or $\mathrm{pH}$ may inactivate the virus, others like certain salt supplements are able to stabilize the infectivity of the virus. 
Weiss, K. et al. / American Journal of Biochemistry and Biotechnology 8 (2) (2012) 81-98

Table 2. Cell type and MV strain for MV production. Summary of the main virus strains which were produced with different cell lines. For better comparability, titers in pfu were converted in $\mathrm{TCID}_{50}$ by multiplication with the factor 0.7

\begin{tabular}{|c|c|c|c|}
\hline MV strain & Cell line & $\begin{array}{l}\text { max. titer }\left(\times 10^{6}\right. \\
\left.\text { TCID }_{50} / \mathrm{mL}\right)\end{array}$ & Ref. \\
\hline \multirow[t]{17}{*}{ Edmonston } & $\mathrm{AV}_{3}$ & 2.800 & (Scott and Choppin, 1982) \\
\hline & BGMK & 154.000 & (Scott and Choppin, 1982) \\
\hline & BHK-21 & 0.014 & (Scott and Choppin, 1982) \\
\hline & BSC-1 & 14.000 & (Nakai et al., 1969) \\
\hline & $\mathrm{CV}-1$ & 28.000 & (Scott and Choppin, 1982) \\
\hline & $\mathrm{HeLa}$ & 0.046 & (Romano and Scarlata, 1973) \\
\hline & & 70.000 & (Udem, 1984) \\
\hline & Hep-2 & 8.400 & (Scott and Choppin, 1982) \\
\hline & & 0.630 & (Black, 1959) \\
\hline & KB & 0.560 & (Kohn and Yassky, 1962) \\
\hline & MA160 & 230.000 & (Baczko and Lazzarini, 1979) \\
\hline & MDCK & 0.007 & (Scott and Choppin, 1982) \\
\hline & PK-15 & 0.007 & (Scott and Choppin, 1982) \\
\hline & U937 & 8.600 & (Brandriss et al., 1982) \\
\hline & Vero & 196.000 & (Scott and Choppin, 1982) \\
\hline & & 170.000 & (Mendonca et al., 1994) \\
\hline & & 8.000 & (Mendonca et al., 2002) \\
\hline \multirow[t]{2}{*}{ AIK-C } & MRC-5 & $100,000.000$ & (Trabelsi et al., 2010) \\
\hline & & 10.000 & (Trabelsi et al., 2012) \\
\hline \multirow[t]{2}{*}{ Leningrad-16 strain } & quail embryo cells & 10.000 & (Boriskin et al., 1988) \\
\hline & & 0.360 & (Sidorenko et al., 1989) \\
\hline TYCSA & Vero & 3.000 & (Shishido et al., 1967) \\
\hline Halle & & 70.000 & (Scott and Choppin, 1982) \\
\hline
\end{tabular}

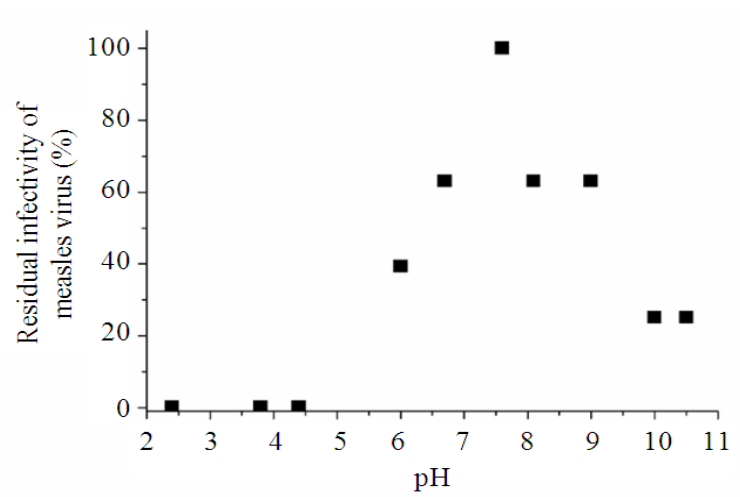

Fig. 3. Residual infectivity of measles virus at various $\mathrm{pH}$. MV was mixed with two volumes of cold buffer solutions of various $\mathrm{pH}$ values and incubated for $3 \mathrm{~h}$ in an ice bath. Determination of the virus titer was evaluated by titration (plaque method). Infectivity was normalized to optimal $\mathrm{pH} 7.6$ and residual infectivity is plotted against $\mathrm{pH}$. Figure is based on data published by Black (1959).

Temperature dependent inactivation of $\mathrm{MV}$ at $37^{\circ} \mathrm{C}$ has been reported to proceed at a rate of about $0.15 \log _{10}$ units per hour, which represents a viral half-life of about two hours (Black, 1959). Kohn and Yassky (1962) also reported a high inactivation rate of MV at $37^{\circ} \mathrm{C}$, with a drop in infectivity by $90 \%$ in $16 \mathrm{~h}$ or $1.4 \log _{10}$ units per $24 \mathrm{~h}$. Due to MV's high susceptibility to temperature-inactivation (Black, 1959; Kohn and Yassky, 1962), there has been considerable interest in stabilizing the virus. Rapp et al. (1965) reported the impact of various salt solutions on the stability of MV. Dilutions of infectious particle preparations in $1 \mathrm{M} \mathrm{MgSO}_{4}$ and $1 \mathrm{M} \mathrm{Na}_{2} \mathrm{SO}_{4}$ stabilized the virus. In contrast, in other salt solutions $\left(\mathrm{CaCl}_{2}, \mathrm{NaCl}, \mathrm{KCl}, \mathrm{K}_{2} \mathrm{SO}_{4}\right.$ and $\left.\mathrm{Na}_{2} \mathrm{HPO}_{4}\right)$, or in pure water, a decrease of one to more than three $\log _{10}$ units was observed within $15 \mathrm{~min}$ at $50^{\circ} \mathrm{C}$. With $\mathrm{MgSO}_{4}$ and $\mathrm{Na}_{2} \mathrm{SO}_{4}$, only slight decreases of 0.2 or $0.4 \log _{10}$ units, respectively, were observed. Furthermore, MV inactivation at $50^{\circ} \mathrm{C}$ decreased with increasing $\mathrm{MgSO}_{4}$ concentration. However, an increasing concentration of $\mathrm{MgCl}_{2}$ enhanced the inactivation of MV. These results indicate that sulfate ions may protect MV against thermal inactivation (Rapp et al., 1965).

Boriskin et al. (1988) analyzed the impact of $\mathrm{MgSO}_{4}$ on MV yields, again (Boriskin et al., 1988). Here, the same thermal inactivation rate of MV in the absence and presence of $\mathrm{MgSO}_{4}$ was observed. It has been suggested that sulfate ions cannot protect the virus from heat inactivation in contrast to the previously cited publication (Rapp et al., 1965). As an explanation for this discrepancy, the addition of $\mathrm{MgSO}_{4}$ to the culture medium was described to result in earlier plaque formation and thus in an increase of apparent titers by up to 200-fold. $\mathrm{MgCl}_{2}$ supplementation showed no stimulating effect and the addition of $\mathrm{Na}_{2} \mathrm{SO}_{4}$ showed a 
maximum virus increase of apparent titer of only 10 -fold (Boriskin et al., 1988). Thus, certain ions may increase virus production or infectivity, but not its stability. This was further documented by analyzing MV NP protein synthesis by radioimmune precipitation and SDSPAGE, where MV ribonucleocapsid protein appears in untreated cells to a much lesser extent, as compared to $\mathrm{MgSO}_{4}$ treated cells (Boriskin et al., 1988).

The $\mathrm{pH}$ sensitivity of MV has also been analyzed. Figure 3 presents residual infectivity of MV at various pH (Black, 1959) showing a highest stability at pH 7.6 and a progressive inactivation of $\mathrm{MV}$ for both acidification and alkalinization results.

MV particles are highly susceptible to temperature and $\mathrm{pH}$ dependent inactivation (Black, 1959; Kohn and Yassky, 1962; Rapp et al., 1965; Boriskin et al., 1988). Therefore it can be concluded, that during production released virus is inactivated very fast in the supernatant. For maximum virus yields, immediate cooling after the harvest, repeated harvesting in at least hourly intervals, further additional analyses for stabilizing the virus particles and online measurements and regulation of the $\mathrm{pH}$ during $\mathrm{MV}$ production are thus required.

\subsection{Extracellular and Cell-Associated Virus}

While production of MV components is inside the infected cell, all parts accumulate at the cell membrane and are released via budding. These active and complete MV particles appear extracellular. Other particles stay cellassociated. In the last phase of virus replication infectious virus as well as non-infectious virus components and particles can be released through cell disruption.

The derivation of the virus preparation is important, since extracellular virus is better to handle, as it is easy to separate from cells. Intracellular virus particles require cell disruption, thereby releasing potential impurities, i.e., cellular and viral components besides infectious particles, into the preparation.

One of the first reports about MV production in Hep2 cells examined extracellular and cell-associated MV concentration during infection (Black, 1959). Although the cell disruption method, a one-step freeze-thaw cycle at $-5^{\circ} \mathrm{C}$, was referred to as incomplete, the amounts of extracellular virus were always lower than cell-associated yields. Infectious cell-associated virus had been found first after $15-18 \mathrm{~h}$ p.i. and extracellular virus could be observed about $26 \mathrm{~h}$ post infection. For both, maximum virus titers appeared after $48 \mathrm{~h}$ p.i. While cell-associated virus titers decreased after $48 \mathrm{~h}$ p.i. the yields for extracellular virus remained constant suggesting continuous virus release. This was confirmed by thermalstability studies, as well. As previously mentioned, MV has a half-life of $2 \mathrm{~h}$ at $37^{\circ} \mathrm{C}$ (Black, 1959). Extracellular virus titer could remain constant, because there seems to be equilibrium between virus release and decay.

In another study by Nakai et al. (1969) the yields of released virus and cell-associated virus were always within the same range (maximum titers of approximately $5 \times 10^{6}$ pfu $\left.\mathrm{mL}^{-1}\right)$. Higher extracellular yields appeared with increasing cell-associated virus titers, also suggesting a continuous budding of virus particles (Nakai et al., 1969). Interestingly, HeLa cells showed temperature dependant virus release. While at $37^{\circ} \mathrm{C}$ between a maximum of $\sim 80$ and $98 \%$ of the virus particles remained cell-associated, at $32.5^{\circ} \mathrm{C}$ more than $50 \%$ of the virus had been released not later than $60 \mathrm{~h}$ p.i. (Udem, 1984).

Shishido et al. (1967) infected Vero cells with a variant of the Toyoshima strain; MV titers started to increase for cell-associated virus about $12 \mathrm{~h}$ after infection, for extracellular virus about $18 \mathrm{~h}$ p.i. Titers decreased after $72 \mathrm{~h}$ p.i. for both, extracellular and cellassociated, virus populations. Maximum yields were about $3 \times 10^{6}$ for cell-associated and $5 \times 10^{5} \mathrm{TCID}_{50} \mathrm{~mL}^{-1}$ for released virus. Except for the end of the cultivation period, cell-associated virus titers were always one to two $\log _{10}$ units higher than extracellular titers (Shishido et al., 1967). Accordingly, released virus in Vero and MA160 cells infected with the Edmonston strain represented only about $10 \%$ of the total amount of infectious virus (Baczko and Lazzarini, 1979). However, concentrations of cell-associated and extracellular virus were similar for BSC-1 cells infected with a virulent Edmonston derivative of $\mathrm{MV}$, whereas attenuated virus remained to more than 95\% cell-associated (Rapp, 1964).

These experiments were all performed in static systems, e.g., petri dishes. In bioreactor cultivation with Vero cells, the extracellular yield for MV of the Edmonston strain was lower than intracellular virus titer, as well. While the extracellular $\mathrm{TCID}_{50}$ per $\mathrm{mL}$ was reduced by the value of about $1.1 \log _{10}$, the total virus titer was only lowered by $0.4 \log _{10}$ (Mendonca et al., 1994).

Using the suspension cell line U937 in spinner system, less than $20 \%$ of the total amount appeared extracellular in spinner flasks (Brandriss et al., 1982), whereas during production with the suspension cell line MA160 in spinner flasks about $10 \%$ of the total virus had been released (Baczko and Lazzarini, 1979).

Finally, the titers of cell-associated virus have almost always been reported to be higher than extracellular titers. Yields of cell-associated virus were mainly within a range of $50 \%$ up to $98 \%$ of total virus titers. Nevertheless, as already mentioned, serial harvesting of released virus should be considered. Since cell-associated virus can be harvested only once, cumulative titers of extracellular virus could exceed cell-associated yields. 


\subsection{Impact of Medium Composition on Measles Virus Production}

In general, the medium composition has a great impact on the outcome of a production process. There are several components and supplements necessary or advantageous for cell cultivation and therefore virus production. Since the special requirements of infected cells are unknown, there is considerable need for detailed studies concerning these factors.

\subsection{Impact of Serum}

Serum, mostly Fetal Calf Serum (FCS), is generally supplemented to cell culture media as it provides growth factors, vitamins, hormones, amino acids, substances for adhesion and cytokines. It is supplemented for cell culture usually in amounts varying between 3 and $25 \%(\mathrm{v} / \mathrm{v})$. Serum as a preparation of primary material is not completely characterized, but often essential. The use of serum-free fully defined media is often preferred for more robust and reproducible processes especially for the production of therapeutics.

The impact of serum content on MV production was analyzed by producing the Edmonston strain of MV on Vero cells in the absence and presence of $10 \%$ FCS. Titers (pfu per $\mathrm{mL}$ ) were $0.5-1.5 \log _{10}$ units higher with $10 \%$ FCS than without (48 pfu per cell). With increasing FCS concentration (no serum, $2 \%$ and $10 \%$ ) the virus yield increased. Substitution with calf or horse serum resulted in similar effects, although the use of FCS resulted in slightly higher titers. The addition of $10 \mathrm{mM}$ HEPES to FCS (10\%) supplemented medium resulted in a titer of 185 pfu per cell. Cultivation of infected cells without FCS, but with just $10 \mathrm{mM}$ HEPES or just $5 \mu \mathrm{g} \mathrm{mL}^{-1}$ insulin resulted in a virus titer of 65 or 123 pfu per cell, respectively, while the highest amount (191 pfu per cell) was obtained using all supplements (10\% FCS, HEPES and insulin) (Scott and Choppin, 1982).

Using M199 Medium after infection with different supplements (none, $2 \% \mathrm{FCS}, 0.2 \%$ gelatin, or $0.5 \% \mathrm{BSA}$ ) resulted in quite similar titers. The highest titer had been reached with BSA supplemented medium $\left(10^{7} \mathrm{TCID}_{50} \mathrm{~mL}^{-1}\right)$. The lowest titer was equal to $3.2 \times 10^{6}$ TCID $_{50} \mathrm{~mL}^{-1}$ and resulted with M199 medium without any supplements (Trabelsi et al., 2012).

\subsection{Impact of Amino Acids in the Culture Medium}

Most cell lines depend on supplemented amino acids to maintain their metabolism during in vitro cultivation. Two media have been compared with respect to microscopically detectable morphological changes of infected Hep-2 cells (Reissig et al., 1956).
Enders medium contained bovine amniotic fluid, beef embryo extract, heated horse serum and Hanks balanced salt solution. Eagles (1955) medium was supplemented with amino acids and serous enrichments as described and has been additionally supplemented with calf serum. Up to tenfold higher virus yields were observed in Eagles medium compared to Enders medium (exact values had not been published). Additionally, the morphology of the cellular monolayer was different. In Enders medium, the monolayer was transformed into few large syncytia. In Eagles medium, the cells appeared more as a network and became rounded in shape (Fig. 4) (Reissig et al., 1956).

When Enders medium was additionally supplemented with glutamine, the morphology of the cell sheet was similar to that in Eagles medium. The other way around, using glutamine deficient Eagle's medium, the cell morphology corresponds to the morphology of the cells in the normal Enders medium. This result suggests that the morphological changes were due to glutamine omission. Hence, the authors concluded, that the presence or absence of glutamine in the medium was the reason for the different virus titer (Reissig et al., 1956).

The amino acid requirements for MV production have been examined in HeLa cells, as well (Romano and Scarlata, 1973). For that purpose, the omission or addition of certain amino acids (tryptophan, cysteine, tyrosine, leucine, valine, phenylalanine, isoleucine, threonine, methionine, lysine, histidine, glutamine and arginine) was analyzed by comparing plaque formation in the infected cells. The respective amino acids were additionally supplemented to a final concentration of $0.5 \mathrm{mM}$ to Eagle's Basal Medium (EBM) without serum. The results were normalized to titers produced in EBM supplemented with all amino acids and set as $100 \%$. The production of MV in this reference medium reached $4.6 \times 10^{4}$ TCID $_{50} \mathrm{~mL}^{-1}$ (Romano and Scarlata, 1973).

Three amino acids (arginine, methionine and glutamine) exerted major impact on the number of plaques and on virus production. The omission of these three amino acids always reduced MV yields, but the additional supplementation of arginine and glutamine to the higher concentrations of $0.5 \mathrm{mM}$, resulted in increased viral titers. In EBM without arginine, plaque formation was reduced to only $15 \%$. An increase of arginine concentration up to $0.5 \mathrm{mM}$ resulted in 2 fold higher plaque formation. The virus production in arginine-deprived medium resulted in a maximum titer of only $21 \mathrm{TCID}_{50} \mathrm{~mL}^{-1} 48 \mathrm{~h}$ p.i. thus three $\log _{10}$ units lower as compared to the reference. Methionine seems to be an essential amino acid for the production of MV in HeLa cells, as well. The absence of methionine resulted in early cell death, even before plaque formation became evident. 

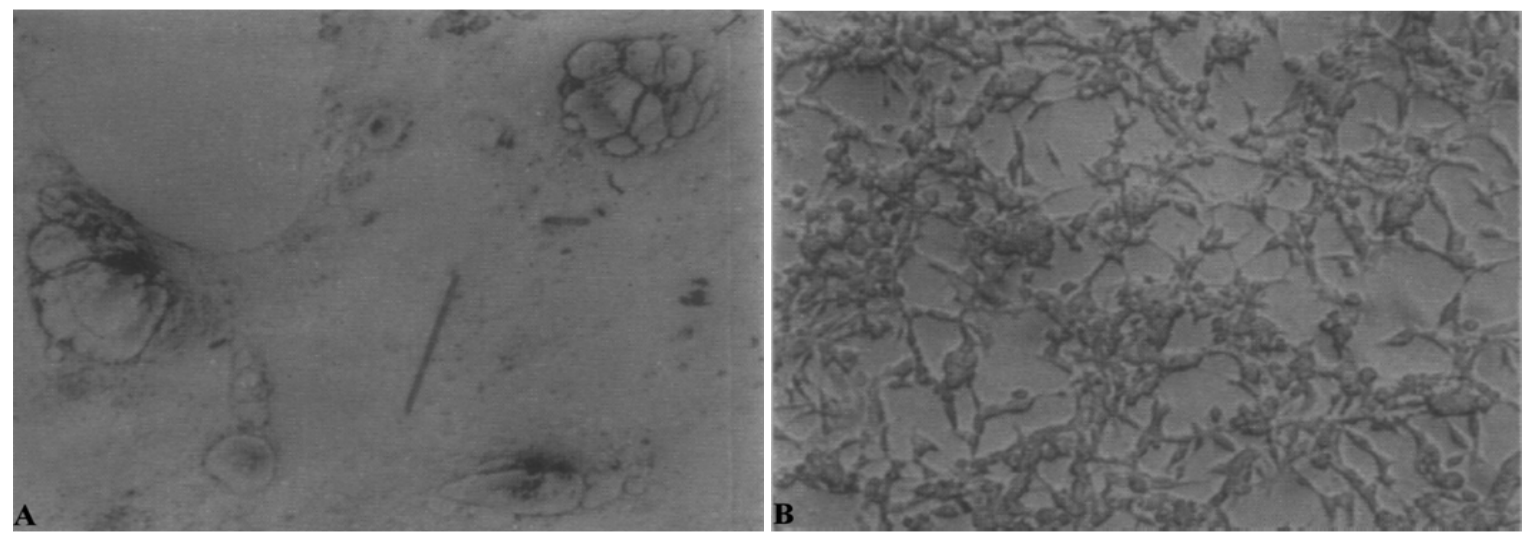

Fig. 4. Morphology of MV-infected Hep-2 cells cultured in different media (obtained from (Reissig et al., 1956), with permission). Hep-2 cells grown in (A) Enders medium supplemented with bovine amniotic fluid, beef embryo extract, heated horse serum and Hanks balanced salt solution or (B) Eagles medium supplemented with amino acids and serous enrichments and calf serum. Cells were infected with the Edmonston strain of MV. Depicted are infected monolayer cultures ten days p.i. Phase contrast, about $60 \mathrm{x}$ magnification.

For virus production without methionine, the titers did not exceed $32 \mathrm{TCID}_{50} \mathrm{~mL}^{-1}$. The increase of methionine up to $0.5 \mathrm{mM}$ did not increase maximum plaque formation above reference. However, addition of $0.5 \mathrm{mM}$ methionine to cells with preceding methionine omission resulted in a three $\log _{10}$ units-fold increase of the virus titer (up to $3.2 \times 10^{3} \mathrm{TCID}_{50} \mathrm{~mL}^{-1}$ ) within the next $10 \mathrm{~h}$. The third essential amino acid, glutamine, had similar effects as methionine. MV infection in the absence of glutamine was accompanied by early cell death without plaque formation. On the contrary, a glutamine concentration of $0.5 \mathrm{mM}$ in the medium caused an increase of plaque formation to 1.5 -fold higher numbers than the reference (Romano and Scarlata, 1973).

Other amino acids had no or a negative impact on MV replication and production. Tryptophan deprivation had no influence on plaque formation, while the addition of $0.5 \mathrm{mM}$ of tryptophan was cytotoxic, resulting in rounded-up cells and a $50 \%$ decrease in plaque formation. The deprivation of isoleucine and threonine caused only $35 \%$ plaque formation and virus titers reached a maximum of $3.2 \times 10^{3}$ and $1 \times 10^{3} \mathrm{TCID}_{50} \mathrm{~mL}^{-1}$ $48 \mathrm{~h}$ p.i. respectively. The omission of the other amino acids resulted in $65-90 \%$ plaque formation, except for the deprivation of lysine, which revealed unchanged plaque formation. Increased concentrations of other amino acids had no influence on plaque formation. The highest MV titer $\left(1 \times 10^{4} \mathrm{TCID}_{50} \mathrm{~mL}^{-1}\right)$, apart from the reference, was reached after $48 \mathrm{~h}$ p.i. in culture medium without tryptophan, lysine, cysteine and glutamine (Romano and Scarlata, 1973).

While reduced titers have been reported by the omission of serum, some components in serum seem to be essential for MV production. As serum is complex and chemically undefined process instability and problems with batch to batch reproducibility are to be expected. Analyzing the available data, the amino acids arginine, methionine and glutamine seem to be important for high titers. However, this may vary with cell line and virus strain. In general, there are too little data available for robust interpretation. The special requirements considering amino acids of the host cells are still unknown, although glutamine has often been reported to be essential for MV production. Kinetic studies should be performed ideally with fully defined synthetic medium, which then enables implementation of optimal nutrient supply for MV production.

\subsection{Impact of Multiplicity of Infection (MOI) on Measles Virus Production}

The MOI describes the ratio of infectious agent (here: MV) to the infection target (cells). In general, MV infection for production purposes is performed at low MOI's around 0.02 (Kohn and Yassky, 1962; Brandriss et al., 1982; Boriskin et al., 1988, Sidorenko et al., 1989; Trabelsi et al., 2010).

Nakai et al. (1969) studied MV production by electron microscopy and varied the MOI. Bundles of filaments with a tubular nature, called tubules, were observed in infected cells' cytoplasm. These tubules were associated with the budding process. With ongoing MV replication, the tubules became larger and more numerous. Therefore, these tubules might be interpreted as MV nucleoprotein aggregates. Additionally, these tubules appeared in the nucleus, as well. These nuclear tubules were observed, when the cells were infected with 
an MOI of 10 . They appeared $24 \mathrm{~h}$ p.i. but they remained very sparse and poorly developed. The resulting extracellular virus titer was $10^{4}$ pfu $\mathrm{mL}^{-1}$ and no budding particles could be detected at any time. With lower MOI, the appearance of well-developed cytoplasmic tubules was observed $18 \mathrm{~h}$ p.i., extensive budding activity was evident after $30 \mathrm{~h}$ p.i. The titer of extracellular virus was three $\log _{10}$ units higher $\left(10^{7}\right.$ pfu $\left.\mathrm{mL}^{-1}\right)$ than the one observed with an MOI of 10 (Nakai et al., 1969).

Preferentially low MOI for producing high-titer MV was also demonstrated for BSC-1 cells. With an MOI of 1 , the titers increased until day 2 p.i. and then remained stable. The highest values were about $1 \times 10^{6}$ and $2 \times 10^{5} \mathrm{pfu} \mathrm{mL}^{-1}$ for cell-associated or extracellular virus, respectively. With a lower MOI of 0.01 , the MV titers increased until day 3 and reached a maximum titer of $5 \times 10^{6} \mathrm{pfu} \mathrm{cell}^{-1}$ for both cell-associated and extracellular virus (Nakai et al., 1969).

For the production in Vero cell monolayers, the impact of MOI was analyzed by increasing the MOI in $\log _{10}$ steps from $0.001-10$ (Scott and Choppin, 1982). All maximum virus titers were between $10^{7}$ and $10^{8}$ pfu $\mathrm{mL}^{-1}$. However, the highest MOI gave rise to the lowest maximum titer. In contrast, the best virus yield was produced with an MOI of 0.01 , but reduction of the MOI elongated the time of virus production by about 5 days (Scott and Choppin, 1982).

In another study, the overall yield of MV production in Vero cell monolayers was higher with an MOI of 0.1 compared to an MOI of 10 . However, using an MOI of 10 , viral titers were higher until $48 \mathrm{~h}$ p.i. but production had to be terminated earlier ( $72 \mathrm{~h}$ MOI $10 \mathrm{vs} .96 \mathrm{~h}$ MOI 0.1) (Baczko and Lazzarini, 1979). In the same report, the titers in MA160 cell monolayers after infection with an MOI of 10 were always higher than titers reported after infection with MOI of 0.1. Again, using an MOI of 10 , virus production had to be terminated one day earlier (96 h p.i. Vs $120 \mathrm{~h}$ p.i. respectively). In contrast, in MA160 suspension culture, the MV titer with MOI 10 were higher until $48 \mathrm{~h}$ p.i. while better titers appeared with an MOI of 0.1 starting $72 \mathrm{~h}$ p.i. until the end (Baczko and Lazzarini, 1979).

In MRC-5 cells the influence of the MOI was studied, too. The MOI was varied in steps of 0.01 , 0.005 and 0.001 . The highest titer was observed with an MOI of $0.01\left(7.5 \times 10^{6} \mathrm{TCID}_{50} \mathrm{~mL}^{-1}\right)$, although the titers with an MOI of 0.005 and 0.001 were only slightly lower $\left(1.8 \times 10^{6}\right.$ and $7.5 \times 10^{5} \quad$ TCID $\left._{50} \mathrm{~mL}^{-1}\right)$ (Trabelsi et al., 2012).

In contrast to the results discussed above, with HeLa cells the more virus particles was produced the higher the MOI (0.01, 0.1 and 1) was. Interestingly, the maximum virus titer increased with increasing $\mathrm{MOI}$ to a more drastic rate at $37^{\circ} \mathrm{C}$ (up to three $\log _{10}$ units) than it did at $32.5^{\circ} \mathrm{C}$ (up to one $\log _{10}$ unit) (Udem, 1984).

In most cases, a lower MOI was reported to be associated with higher viral titers. However, high MOI shortens production time, but increases the amount of virus needed for infection. Since economical consideration play a significant role in optimizing production processes, it should be noted that longer cultivation times and increased amounts for infection (higher MOI) cause higher production costs. On the other hand, with serial virus harvests as suggested above, the longer the time of production, the higher is the total generated virus amount. Thus, total yields with low MOI and serial virus harvests could be beneficial over longer production time in terms of production costs.

\subsection{Impact of Culture Systems for Measles Virus Production}

As already described for monolayer and suspension cultures, the choice of the culture system exerts considerable impact on virus production and the scalability of a process. Potential culture systems for MV production are in the range from small, simple and uncontrolled systems such as monolayer cultivation in T-flask or petri dishes up to highly controlled cultivation systems in large scales (e.g., Stirred Tank Reactors (STR)). Current MV vaccine production is performed mainly in adherent cells. As adherent cell lines usually need a growth surface to attach, the cultivation in a suspension culture such as in bioreactors can be supported by so called microcarriers. These microcarriers, on which the cells can grow, are small round or flat particles, which can easily be suspended by a stirrer.

\subsection{Spinner Flask Cultivation}

Boriskin et al. (1988) first reported MV production with cells cultivated on microcarriers. Quail embryo fibroblasts were cultivated on Cytolar- 2 microcarriers and then infected with the MV strain Leningrad-16. Although the titers from roller bottle and microcarrier cultivation were within the same range, slightly higher virus titers were reached in roller cultures.

MV production with three different microcarriers (Cytodex 2, Micarcel G and Cytolar 2) had been investigated with quail embryo cells, as well (Sidorenko et al., 1989). With Cytodex 2 carriers, the maximum virus titer $\left(6 \times 10^{5} \mathrm{TCID}_{50} \mathrm{~mL}^{-1}\right)$ was reached on day 5 p.i.; afterwards, the virus titer decreased. With Micarcel G carrier, the highest maximum titer $\left(8 \times 10^{5} \mathrm{TCID}_{50} \mathrm{~mL}^{-1}\right)$ was observed on day 4 p.i. For these microcarriers, the maximum MV titer remained constant for about 2 days and decreased following day 6 p.i. The lowest virus yield was measured on Cytolar 2 microcarriers. 
Table 3. MV production performed with host cell cultivation on microcarrier. The respective bioreactor system, microcarrier and cell lined used are presented.

\begin{tabular}{|c|c|c|c|c|c|}
\hline Culture system & Microcarrier & Cell line & MV strain & $\begin{array}{l}\max . \text { Titer }\left(\times 10^{6}\right. \\
\left.\text { TCID }_{50} / \mathrm{mL}\right)\end{array}$ & Ref. \\
\hline \multirow[t]{5}{*}{ Spinner bottles } & Cytolar-2 & quail embryo cells & Leningrad 16 & 3.0 & (Boriskin et al., 1988) \\
\hline & Cytodex 2 & quail embryo cells & Leningrad 16 & 0.6 & (Sidorenko et al., 1989) \\
\hline & Micarcel G & quail embryo cells & Leningrad 16 & 0.8 & \\
\hline & Cytolar 2 & quail embryo cells & Leningrad 16 & 0.4 & \\
\hline & Cytodex 1 & MRC-5 & $\mathrm{AIK}-\mathrm{C}$ & $100,000.0$ & (Trabelsi et al., 2010) \\
\hline \multirow{3}{*}{ Bioreactor (STR) } & Cytodex 1 & MRC-5 & AIK-C & 40.000 .0 & (Trabelsi et al., 2010) \\
\hline & Cytodex 1 & MRC-5 & AIK-C & 10.0 & (Trabelsi et al., 2012) \\
\hline & Cytodex 1 & Vero & Edmonston & 50.0 & (Mendonca et al., 1994) \\
\hline
\end{tabular}

A maximum titer was reached at day 7 p.i. $\left(4 \times 10^{5} \mathrm{TCID}_{50}\right.$ $\mathrm{mL}^{-1}$ ) and decreased thereafter. With microcarrier cultivation, a twofold enhancement of virus yields was obtained at best compared to roller cultures, reaching maximal production rates of 4.5-6.4 TCID $_{50}$ per cell. However, the virus production time and the harvest time was shortened with microcarrier systems. Furthermore, it was reported that MV yields could not be increased by higher microcarrier concentrations or cell densities. Sidorenko et al. (1989) further addressed the problem of determining the viable cell number after infection with MV. The cell number switched back and forth during MV production and determination of viable cell numbers by trypan blue exclusion was suggested to be not an adequate method. Since cells, which are stained blue, are supposed as dead, these cells could still release virus for an unknown time (Sidorenko et al., 1989).

In another report, spinner flask cultures of MRC-5 cells were cultivated on Cytodex 1 microcarriers (Trabelsi et al., 2010). In spinner flasks, the highest cell concentration was reached after 5 days of culture, which was chosen as time of infection. One day after infection with the AIK-C strain, the virus titer increased continuously until 6 days p.i. and reached a maximum titer of $1 \times 10^{11}$ TCID $_{50} \mathrm{~mL}^{-1}$ (Trabelsi et al., 2010).

\subsection{Bioreactor Cultivation}

First data concerning MV production in a bioreactor were published in 1994 using an STR (Mendonca et al., 1994). MV was amplified on MRC-5 cells in an STR grown on Cytodex 1 microcarriers (Trabelsi et al., 2010), but also on a ready-to-use disposable fixed bed system (BelloCell) in Minimal Essential Medium (MEM) and $0.2 \%$ Bovine Serum Albumin (BSA). In the STR, the TCID $_{50}$ per cell and day was at minimum 15 times lower than in the BelloCell System (125 and 1,900 TCID $_{50}$ per cell and day, respectively). Shear stress was suggested to reduce the production yield in the STR (Trabelsi et al., 2010).

Taken the available data together, spinner or bioreactor cultivations are sufficient systems for MV production. Although MV yields were not always higher compared to T-flaks or roller bottles, the bioreactor system could still be advantageous considering the possibility of in-process control and direct regulation of e.g., $\mathrm{pH}$ and oxygenation. Additionally, serial harvesting could easily be automated. With further optimization of bioreactor cultivation, these systems seem to be very promising. MV yields produced with host cells cultivated on microcarriers in either spinner bottles or bioreactors are summarized in Table 3.

\subsection{Impact of Variations in Culture Modes on Measles Virus Production}

Controlled culture systems can work in different culture modes. This includes variation in temperature, stirrer speed, or different feeding and harvesting strategies, which all could influence virus stability and cell growth. The impact of the parameters temperature, shear force, feeding and serial harvests have already been investigated.

\subsection{Impact of Culture Temperature}

The various Edmonston derived vaccine strains have been further attenuated by additional passages in chicken embryo fibroblasts at a reduced temperature $\left(32^{\circ} \mathrm{C}\right)$ (Katz, 2009). In some studies MV were also produced at lower temperature (Kohn, 1962; Boriskin et al., 1988; Mendonca et al., 1994; 2002), but MV production at $37^{\circ} \mathrm{C}$ is common as well (Black, 1959; Shishido et al., 1967, Nakai et al., 1969; Romano and Scarlata, 1973; Brandriss et al., 1982). Consequently, the impact of the cultivation temperature during MV production has already been evaluated.

Amplification of attenuated and virulent Edmonston strains on $\mathrm{BSC}-1$ cells has been reported to be similar at $34^{\circ} \mathrm{C}$ or $37^{\circ} \mathrm{C}$ (Rapp, 1964). A further comparative study of AIK-C strain MV production in MRC-5 cells at $34^{\circ} \mathrm{C}$ or $36^{\circ} \mathrm{C}$ in spinner cultures revealed slightly higher cell numbers with a cultivation temperature of $34^{\circ} \mathrm{C}$, but MV titers were similar at both temperatures, again (Trabelsi et al., 2010).

MV Hallé and Edmonston strains produced at $33^{\circ} \mathrm{C}$ or $37^{\circ} \mathrm{C}$ in Vero cell monolayers resulted in higher yields for the Hallé strain at $33^{\circ} \mathrm{C}$. For the Edmonston strain, the yield was initially higher at 
$37^{\circ} \mathrm{C}$, but the overall yield was better at $33^{\circ} \mathrm{C}$, when a longer production phase was feasible (four instead of two days). For both virus strains, the cultivation at $37^{\circ} \mathrm{C}$ had to be terminated at least two days earlier than those at $33^{\circ} \mathrm{C}$. This effect was supposed to be caused by the lytic nature of MV, which seems to be more intensive at higher temperatures (Scott and Choppin, 1982).

In HeLa cells MV yields were up to three folds higher (two $\log _{10}$ units) at $32.5^{\circ} \mathrm{C}$ than at $37^{\circ} \mathrm{C}$. Additionally, the author demonstrated that higher yields were not due to temperature sensitivity. The titers of 20 virus clones grown at $32.5^{\circ} \mathrm{C}$ were nearly the same $(+/-$ $10 \%$ ) when plated at 32.5 and $37^{\circ} \mathrm{C}$. Thus, it was suggested that host cell factors, such as protein synthesis, or a temperature-dependent host cell protease needed for the processing of virus polypeptides could be altered at the different temperatures (Udem, 1984).

\subsection{Impact of Shear Forces}

Mechanical shear forces have been published to increase MV yield from static monolayer cultures. Vigorous agitation could raise the virus titer about 2.512.5-fold in the supernatant. Since the mechanical forces did not increase cellular contaminants in the supernatant, it was suggested that the increase could be due to MV particles, whose budding was assisted by the help of the mechanical forces. As this vigorous agitation was performed in static cultures, higher virus yields in bioreactor cultivations with permanent shear forces could be suggested (Wechsler et al., 1985). However, the agitation in static cultures was performed for the short time of harvest and not extensively during cultivation, thus it remains unclear, which effect a durable shear force during the whole cultivation period, as found in bioreactor systems, has got. Additionally, as serum is a protective agent concerning shear stress, it should be noted that the medium in the T-flasks had been replaced with serum-free medium 12-18 hours prior to the harvest (Wechsler et al., 1985).

\subsection{Impact of Culture Mode}

Repeated batch and perfusion mode have been compared in an STR (Trabelsi et al., 2010). These data revealed an approximately 6-fold higher virus yield in the repeated batch mode $\left(125 \mathrm{TCID}_{50}\right.$ per cell and day), compared to the perfusion mode (21 TCID 50 per cell and day).

In another study it has been demonstrated, that appropriate feeding of the cells is advantageous for MV production (Mendonca et al., 2002). The analysis of the effects of glutamine or galactose feeding on the growth of Vero cells on Cytodex 1 microcarriers and subsequent MV production are summarized in Table 4
(Mendonca et al., 2002). MV yields were successfully raised by increasing the cell number by feeding, as well. Infection on the fourth day of cultivation, when the batch cultivation was terminated, resulted in a virus titer of $5 \times 10^{6} \mathrm{TCID}_{50} \mathrm{~mL}^{-1} 5$ days post infection. Without feeding, the cell number was drastically reduced until the 12th day of cultivation and infection of these cells resulted in a low virus yield 5 days p.i. However, with galactose and glutamine feeding, infection of 12 days old cultures resulted in a titer of $8 \times 10^{6} \mathrm{TCID}_{50} \mathrm{~mL}^{-1}$, again on day 5 p.i. The feeding resulted in a very significant reduction of the percentage of apoptotic cells on the day of infection. As illustrated in Table 4, the virus titer per cell increases with a reduced rate of apoptotic cells. These data reveal that an optimized production process for the cell line could lead to higher MV production rates (Mendonca et al., 2002).

\subsection{Impact of Harvesting Strategies}

Overall virus yields have been reported to be enhanced by repeated harvest of released virus, when conditioned medium from infected monolayers has been replaced with fresh medium (Scott and Choppin, 1982). When considering the comparatively low half-life of the virus at $37^{\circ} \mathrm{C}$ (i.e., $2 \mathrm{~h}$ ) (Black, 1959), this procedure might be promising. Interestingly, only slightly lower virus titers in the culture medium have been reported, when the medium was fully exchanged one hour prior to sampling (Black, 1959). This indicates some kind of equilibrium between release and decay and therefore suggests that a considerable amount of virus is wasted if serial harvesting from the culture medium is omitted. The effect of harvest time has also been investigated (Scott and Choppin, 1982). A single harvest on the fourth day p.i. resulted in yields of 28 pfu per cell for extracellular and 188 pfu per cell for cell-associated virus, which represents a ratio of released-to-cell-associated virus of about 1:6.7. Increasing the numbers of virus harvests from the supernatant resulted in higher released to cell-associated ratios for cumulative yields, respectively in values of 1:3.6 for one additional harvest on day 2 p.i. and 1:2.4 for three additional harvests on days 2.5, 3 and 3.5 p.i. With a total of 4 harvests, maximum numbers of 270 and 651 pfu per cell for extracellular and cellassociated virus, respectively, have been determined. This positive effect appeared always, when the time point of the first harvest was chosen at day 2 p.i. or later (Scott and Choppin, 1982). Daily harvesting of extracellular virus starting 24 h. p.i. resulted in reduced yields of 22 and 58 pfu cell ${ }^{-1}$ for extracellular and cell-associated virus titers, respectively. The authors suggested that under these circumstances the medium removal one day after inoculation did not allow enough cells to become initially infected (Scott and Choppin, 1982). 
Weiss, K. et al. / American Journal of Biochemistry and Biotechnology 8 (2) (2012) 81-98

Table 4. Effect of feeding on MV yield and cell viability, summary of data published by Mendonca et al. (2002). Presentation of the effect of feeding on apoptosis of cells and measles virus yield

\begin{tabular}{|c|c|c|c|c|c|}
\hline \multirow[b]{2}{*}{ Day of infection } & \multirow{2}{*}{$\begin{array}{l}\text { Cell density at time } \\
\text { of infection } \\
\left(\times 10^{5} \text { cells } \mathrm{mL}^{-1}\right)\end{array}$} & \multirow{2}{*}{$\begin{array}{l}\text { Apoptotic cells at } \\
\text { day of infection } \\
\text { (\% of cells) }\end{array}$} & \multirow[b]{2}{*}{ Feeding ${ }^{a}$} & \multicolumn{2}{|l|}{ MV yield 5 days p.i. } \\
\hline & & & & $\left(\times 10^{6} \mathrm{TCID}_{50} \mathrm{~mL}^{-1}\right)$ & $\left(\mathrm{TCID}_{50}\right.$ per cell $\left.{ }^{\mathrm{b}}\right)$ \\
\hline 4 & 5.1 & 2 & no & 5 & 9.8 \\
\hline 12 & 3 & 88 & no & 0.00052 & 0.002 \\
\hline 12 & 9.2 & 12 & yes & 8 & 8.7 \\
\hline
\end{tabular}

${ }^{\mathrm{a}}$; Fed with $4 \mathrm{mM}$ galactose and $2 \mathrm{mM}$ glutamine at days $4,6,8$ and $10 ;{ }^{\mathrm{b}}:$ Correlated to the cell number at time of infection

Table 5. Summary of published data for MV production. MV yields with respect to the MOI, the scale or mode of cultivation, virus strains and cell lines are presented. For better comparability, titers in pfu were converted in $\mathrm{TCID}_{50}$ by multiplication with the factor 0.7

\begin{tabular}{|c|c|c|c|c|c|c|}
\hline $\begin{array}{l}\text { Max. Titer }(\times \\
10^{6} \\
\left.\text { TCID }_{50} / \mathrm{mL}\right) \\
\end{array}$ & MOI & $\begin{array}{l}\text { Cells/ } \\
\text { MV strain }\end{array}$ & $\begin{array}{l}\text { Cell-associated } \\
\text { /extracellular MV }\end{array}$ & $\begin{array}{l}\text { Scale/ mode } \\
\text { of production }\end{array}$ & Remarks & Ref. \\
\hline- & 1 & CV-1/ not specified & extracellular & $150 \mathrm{~cm}^{2} \mathrm{~T}$-flasks & $\begin{array}{l}\left(33^{\circ} \mathrm{C} \mathrm{p} . \mathrm{i} .\right) \text {, increased yield } \\
\text { by vigorous agitation }\end{array}$ & (Wechsler et al., 1985) \\
\hline 0.046 & $2-5$ & $\begin{array}{l}\text { HeLa/ DP line of the } \\
\text { Edmonston strain }\end{array}$ & - & $\begin{array}{l}16 \mathrm{~cm} \text { rubber stoppered } \\
\text { bottles, roller drum }\end{array}$ & $\begin{array}{l}\text { examining amino acid } \\
\text { deprivation during } \\
\text { MV growth, }\left(37^{\circ} \mathrm{C} \text { p.i. }\right)\end{array}$ & (Romano and Scarlata, 1973) \\
\hline 0.36 & 0.01 & $\begin{array}{l}\text { quail embryo cells/ } \\
\text { Leningrad-16 strain }\end{array}$ & - & $\begin{array}{l}\text { siliconized } 1 \mathrm{~L} \text { spinner, } \\
\text { working volume } 0.5 \mathrm{~L}\end{array}$ & $\begin{array}{l}\text { Cytodex 2, Micarcel G, } \\
\text { Cytolar } 2 \text { (each with } 20 \mathrm{~g} / \mathrm{L} \text { ) }\end{array}$ & (Sidorenko et al., 1989) \\
\hline 0.56 & $\begin{array}{l}0.025 \\
0.01\end{array}$ & $\begin{array}{l}\text { KB cells / Edmonston } \\
\text { strain }\end{array}$ & $\begin{array}{l}\text { cell-associated / } \\
\text { extracellular }\end{array}$ & $\begin{array}{l}\text { petri dishes (50 } \\
\mathrm{mm} \text { dish) }\end{array}$ & $\begin{array}{l}\left(37^{\circ} \mathrm{C} \mathrm{p} . \mathrm{i}\right), \mathrm{MV} \text { inactivation } \\
\text { kinetics at } 37^{\circ} \mathrm{C}\end{array}$ & (Kohn and Yassky, 1962) \\
\hline 0.63 & 1.5 & $\begin{array}{l}\text { Hep-2/ Edmonston } \\
\text { strain }\end{array}$ & $\begin{array}{l}\text { cell-associated / } \\
\text { extracellular }\end{array}$ & - & $\begin{array}{l}\text { growth curves of MV, } \\
\text { characterization of temperature } \\
\text { and pH-sensitivity, }\left(37^{\circ} \mathrm{C} \text { p.i. }\right)\end{array}$ & (Black, 1959) \\
\hline 3 & 1.4 & $\begin{array}{l}\text { Vero/ TYCSA strain } \\
\text { (variant of the } \\
\text { Toyoshima strain) }\end{array}$ & extracellular & $\begin{array}{l}\text { roller tubes with } 1 \\
\text { mL fluid }\end{array}$ & $\left(37^{\circ} \mathrm{C}\right.$ p.i.) & (Shishido et al., 1967) \\
\hline 8 & 0,1 & $\begin{array}{l}\text { Vero / Edmonston } \\
\text { strain }\end{array}$ & extracellular & $\begin{array}{l}\text { T-flasks or spinner } \\
\text { bottles at } 60 \mathrm{rpm} \text {, }\end{array}$ & $\begin{array}{l}\text { Cytodex } 1(2 \mathrm{~g} / \mathrm{L}) \text {, } \\
\text { cells are fed with galactose and } \\
\text { glutamine, }\left(33^{\circ} \mathrm{C} \text { p.i. }\right)\end{array}$ & (Mendonca et al., 2002) \\
\hline 8.6 & 0.02 & $\begin{array}{l}\text { U937 / Edmonston } \\
\text { strain }\end{array}$ & $\begin{array}{l}\text { cell-associated / } \\
\text { extracellular, } \\
\text { daily }\end{array}$ & $\begin{array}{l}\text { suspension cells, } \\
\text { spinner }\end{array}$ & $\left(37^{\circ} \mathrm{C}\right.$ p.i. $)$ & (Brandriss et al., 1982) \\
\hline 10 & 0.03 & $\begin{array}{l}\text { quail embryo cells / } \\
\text { Leningrad-16 strain }\end{array}$ & - & $\begin{array}{l}\text { stationary monolayer, } \\
\text { roller or microcarrier } \\
\text { cultures }(0.5 \mathrm{~L} \text { Techno } \\
\text { cell stirrer bottles })\end{array}$ & MC: Cytolar 2, $\left(33^{\circ} \mathrm{C}\right.$ p.i. $)$ & (Boriskin et al., 1988) \\
\hline 10 & $\begin{array}{l}0.01 \\
0.001 \\
0.005\end{array}$ & $\begin{array}{l}\text { MRC-5/ AIK-C } \\
\text { strain }\end{array}$ & - & $\begin{array}{l}\text { STR } 3 \mathrm{~L} \text { working } \\
\text { volume }\end{array}$ & $\begin{array}{l}\text { Cytodex } 1(3 \mathrm{~g} / \mathrm{L}) \text {, } \\
\text { MOI variation, different } \\
\text { culture modes }\end{array}$ & (Trabelsi et al., 2012) \\
\hline 14 & $\begin{array}{l}0.01-1 \\
10\end{array}$ & $\begin{array}{l}\text { BSC-1, primary rhesus } \\
\text { monkey kidney cells/ } \\
\text { Edmonston }\end{array}$ & $\begin{array}{l}\text { cell-associated / } \\
\text { extracellular }\end{array}$ & $\begin{array}{l}\text { 4-ounce prescription } \\
\text { bottles. }\end{array}$ & $\left(37^{\circ} \mathrm{C}\right.$ p.i. $)$ & (Nakai et al., 1969) \\
\hline 70 & $0.01-1$ & $\mathrm{HeLa} /$ Edmonston & $\begin{array}{l}\text { cell-associated / } \\
\text { extracellular }\end{array}$ & suspension cells & (37 and $32.5^{\circ} \mathrm{C}$ ) & (Udem, 1984) \\
\hline 170 & 0.5 & $\begin{array}{l}\text { Vero/Edmonston } \\
\text { strain }\end{array}$ & $\begin{array}{l}\text { cell-associated / } \\
\text { extracellular, until } \\
\text { cytopathic effect } \\
\text { (96-120 h p.i.) }\end{array}$ & $\begin{array}{l}\text { Celligen cell culture } \\
3.7 \mathrm{~L}, 60 \mathrm{rpm} \text {, for } \\
\text { comparison also } \\
\text { roux bottles }\end{array}$ & $\begin{array}{l}\text { Cytodex } 1 \\
(2 \mathrm{~g} / \mathrm{L}),\left(33^{\circ} \mathrm{C} \text { p.i. }\right)\end{array}$ & (Mendonca et al., 1994) \\
\hline 230 & $0.1,10$ & $\begin{array}{l}\text { MA160, Vero/ } \\
\text { Edmonston strain }\end{array}$ & $\begin{array}{l}\text { cell-associated/ } \\
\text { extracellular }\end{array}$ & $\begin{array}{l}\text { monolayers }\left(75 \mathrm{~cm}^{2}\right) \\
\text { and suspension cultures }\end{array}$ & - & (Baczko and Lazzarini, 1979) \\
\hline 400 & $0,001-10$ & $\begin{array}{l}\text { HEp-2, AV3, BHK- } \\
\text { 21, PK-15, MDCK, } \\
\text { Vero, BGMK / Halle } \\
\text { or Edmonston strain }\end{array}$ & mainly extracellular & flasks, monolayers & $\begin{array}{l}\text { investigation of: } \\
\text { FCS, temperature ( } 33 \\
\text { and } 37^{\circ} \mathrm{C} \text { ), buffer, insulin, } \\
\text { virus strain, cell line, MOI }\end{array}$ & (Scott and Choppin, 1982) \\
\hline 100,000 & 0.01 & MRC-5/ AIK-C strain & - & $\begin{array}{l}\text { packed bed (BelloCell } \\
\text { disposable); STR } 2 \mathrm{~L} \\
\text { (working volume } 1.2 \mathrm{~L} \text { ); } \\
\text { spinner (working } \\
\text { volume } 0.5 \mathrm{~L} \text { ) }\end{array}$ & $\begin{array}{l}\text { Cytodex } 1(3 \mathrm{~g} / \mathrm{L}) \text {, various } \\
\text { cell culture modes, comparison } \\
\text { of virus titers and cell } \\
\text { concentrations, spinner: } \\
\left(36 \text { and } 34^{\circ} \mathrm{C} \text { p.i. }\right) \text {, bioreactor: } \\
\left(34^{\circ} \mathrm{C} \text { p.i. }\right)\end{array}$ & (Trabelsi et al., 2010) \\
\hline
\end{tabular}

However, this interpretation stays in contrast to reports describing that MV inactivation proceeds within few hours and first progeny virus appears already $12 \mathrm{~h}$ after infection (Black, 1959). 
The few available data for MV production suggest that feeding and repeated harvesting are advantageous for high virus yields. The culture temperature and shear stress can affect the total yield ambivalently. However, more detailed studies of these parameters might be considered.

\subsection{Summary}

Table 5 summarizes the currently available data for MV production with respect to the MOI, the scale or mode of cultivation, virus strains and cell lines. For better comparability, titers in pfu were converted in TCID $_{50}$ by multiplication with the factor 0.7 .

\section{CONCLUSION}

Due to its ability of efficient tumor cell killing, MV has been identified as a potential oncolytic virus. Thus, there is considerable interest of a scalable, reproducible, optimized, standardized and automated production process for this promising agent.

Since being established for several decades, MV production for vaccination purposes is not exploiting the technical possibilities offered by modern cell culture technologies. However, simply up-scaling of the robust and established traditional technologies may be difficult when trying to push the viral yield by a factor of up to a million. In addition, potential second generation MV agents with modified tumor-selective cell-entry do most likely not infect traditional cell substrates used for producing parental vaccine MV.

Additionally, economic considerations play an important role for optimizing a biomedical production process. A great factor concerning costs is the scale of a process. It is a big difference whether production is performed in static systems as T-flasks and roller bottles, or in a bioreactor. For example, a bioreactor cultivation with $1 \mathrm{~L}$ working volume and Cytodex 1 microcarriers at a concentration of $3 \mathrm{~g} \mathrm{~L}^{-1}$ confers the same surface area for cell growth as $44 \mathrm{~T}$-flasks (each $300 \mathrm{~cm}^{2}$ surface) or approx. 16 roller bottles (each $850 \mathrm{~cm}^{2}$ ). By this example, it is quite obvious that requirements for media, space and manpower are much less for the bioreactor cultivation. Bioreactor cultivation would be a good alternative to generate the amounts of MV needed for a routine therapeutic cancer treatment, since all other (including traditional) culture systems may be hard to scale up or even do not provide the necessary cell numbers and densities. The feasibility of bioreactor cultivation systems for MV production has already been demonstrated (Mendonca et al., 1994; Mendonca et al., 2002; Trabelsi et al., 2010). As promising the bioreactor cultivation is, there is unfortunately only little data available referring to MV production in such systems. Additionally, further aspects like oxygen demand or shear stress have to be considered.

An optimization of different factors (temperature, MOI, addition of salts and repeated harvesting) has already been investigated in the past. Some of these factors are very important, as e.g., the relative high sensitivity of the MV to temperatures (Black, 1959), or the potential to protect MV particles or promote infectivity by certain salts, respectively (Rapp et al., 1965; Boriskin et al., 1988). Referring to extracellular virus yields, the temperature sensitivity of the virus could be a critical parameter, as well. Virus in the supernatant is inactivated by elevated temperatures, which could be a reason for cell-associated virus yields being almost always reported to be higher than extracellular yields (Black, 1959; Rapp, 1964; Shishido et al., 1967; Nakai et al., 1969; Mendonca et al., 1994). Since studies utilizing lowered temperatures during MV production revealed only slightly higher or similar virus titers (Rapp et al., 1965; Scott and Choppin, 1982; Trabelsi et al., 2010), this attempt may not be too promising. Having this in mind, it could be advantageous to integrate repeated or even continuous harvesting of extracellular virus with immediate cooling of the harvested virus into the process. Hence cell-associated virus can only be harvested once, total amounts of released virus from repeated harvests could exceed the amounts of cell-associated virus.

The addition of FCS provides serum proteins and essential amino acids for virus production. Accordingly, MV yields were almost always higher with serum supplemented medium (Scott and Choppin, 1982). Addition of serum is a critical factor, as it is of an unknown composition and therefore limits the reproducibility of a process. Furthermore, serum complicates the purification steps following production, since the product should be free of any contaminations when applied to human patients e.g., in cancer therapy. Thus, modern cultivation systems tend to rely on serum free cultivation, with complete serum free media being commercially available that can support comparable growth of host cells (Rourou et al., 2007) and therefore high MV yields, too. Regarding medium composition, specific amino acids revealed a strong impact on MV growth (Romano and Scarlata, 1973) and appropriate feeding of Vero cells prior to MV infection also increased the MV yields (Mendonca et al., 2002). However, the available data also indicate that a lot more factors influence MV production, accumulating in the need for detailed kinetic studies.

Besides exogenous factors the virus-cell system has to be optimized, as well. This includes that certain MV strains are adapted for growth in specific cell lines. Additionally, the ratio of virus per cell (MOI) is an important factor to consider. A low MOI around 0.01 reproducibly resulted in the highest MV titers (Nakai et al., 1969; Baczko and Lazzarini, 1979; Scott and Choppin, 1982), but causes an elongated time of cultivation. Furthermore, high MOI reduced budding 
of virus particles (Nakai et al., 1969) and thus shifts the balance to cell-associated virus, which is more difficult to purify.

Processing for scale up systems in the field of cell culture has been performed over the past 50 years. Dynamic cultivations for mammalian cells have been operated from spinner systems up to bioreactors with working volumes up to several hundreds of liters (Eibl et al., 2008). Development of microcarrier system made such cultivation modes possible for adherent cell cultures, as well. Moreover, the bioreactor cultivation should be an easy method to improve the space-time-yield and the microcarrier system seems to be a proper operation mode for the production of MV (Boriskin et al., 1988; Sidorenko et al., 1989; Mendonca et al., 1994; Mendonca et al., 2002; Trabelsi et al., 2010). Much effort in standardized bioreactor cultivation with mammalian cells has been done. The growing use of disposable systems such as single-use bags for bioreactors, sensors, sampling or seed inoculums further advanced the cultivations (Eibl et al., 2008).

For MV production, further efforts should concentrate on the following developments:

- A production process, which enables an easy scale up of the respective microcarrier systems

- As FCS is an undefined substance, MV should be produced in serum free medium

- Appropriate feeding of the cells during growth and virus production, which is based on detailed kinetic studies

- An established offline analytic would help integrating methods for online measurements and process automation

- The integration of an automated tool for serial or even continuous harvests

Solving these tasks should allow the set-up of an optimized, versatile production process, resulting in measles virus preparations intended for the use as oncolytic agents in the desired quality and quantities under affordable conditions.

\subsection{Conflict of interest}

The authors declare no conflict of interest.

\section{ACKNOWLEDGEMENT}

The researchers would like to thank the Hessen State Ministry of Higher Education, Research and the Arts for the financial support within the Hessen initiative for scientific and economic excellence (LOEWE-program).

\section{REFERENCES}

Artenstein, A.W., 2009. Vaccines: A Biography. 1st Edn., Springer, New York, ISBN-10: 1441911073, pp: 401.

Baczko, K. and R.A. Lazzarini, 1979. Efficient propagation of measles virus in suspension cultures. J. Virol., 31: 854-855. PMID: 513197

Black, F.L., 1959. Growth and stability of measles virus. Virology, 7: 184-192. DOI: 10.1016/00426822(59)90186-2

Blechacz, B., P.L. Splinter, S. Greiner, R. Myers and K.W. Peng et al., 2006. Engineered measles virus as a novel oncolytic viral therapy system for hepatocellular carcinoma. Hepatology, 44: 14651477. DOI: $10.1002 /$ hep. 21437

Boriskin, Y.S., L.L. Steinberg, L.V. Dorofeeva, I.N. Zasorina and E.P. Barkova, 1988. Salt-induced enhancement of measles virus yields in cultured cells. Arch Virol., 101: 131-136. DOI: 10.1007/BF01314658

Brandriss, M.W., J.J. Schlesinger and S.E. Chapman, 1982. Growth of measles virus in a human macrophagelike cell line: U937. Am. J. Pathol., 109: 179-183.

Bronzino, J.D., 2000. The Biomedical Engineering Handbook. 2nd Edn., Springer, Boca Raton, ISBN10: 354066808X, pp: 1408.

Cathomen, T., B. Mrkic, D. Spehner, R. Drillien and R. Naef et al., 1998. A matrix-less measles virus is infectious and elicits extensive cell fusion: Consequences for propagation in the brain. EMBO J., 17: 3899-3908. DOI: 10.1093/emboj/17.14.3899

Davis, J.J. and B. Fang, 2005. Oncolytic virotherapy for cancer treatment: challenges and solutions. J. Gene Med., 7: 1380-1389. DOI: 10.1002/jgm.800

Dorig, R.E., A. Marcil, A. Chopra and C.D. Richardson, 1993. The human CD46 molecule is a receptor for measles virus (Edmonston strain). Cell, 75: 295-305. DOI: 10.092-8674(93)80071-L

Dubois-Dalcq, M. and T.S. Reese, 1975. Structural changes in the membrane of vero cells infected with a paramyxovirus. J. Cell Biol., 67: 551-565. DOI: $10.1083 / \mathrm{jcb} .67 .3 .551$

Eagle, H., 1955, Nutrition needs of mammalian cells in tissue culture. Science, 122: 501-514. DOI: 10.1126/science. 122.3168 .501

Eibl, R., D. Eibl and R. Pörtner, 2008. Cell and Tissue Reaction Engineering. 1st Edn., Springer, Berlin, ISBN-10: 3540681752, pp: 363.

Enders, J.F. and Peebles, T.C., 1954. Propagation in tissue cultures of cytopathogenic agents from patients with measles. Proc Soc Exp. Biol. Med., 86: 277-286. DOI: 10.3181/00379727-86-21073 
Enders, J.F., S.L. Katz, M.V. Milovanovic and A. Holloway, 1960. Studies on an attenuated measles-virus vaccine. I. Development and preparations of the vaccine: Technics for assay of effects of vaccination. New England J. Med., 263: 153-159. DOI: 10.1056/NEJM196007282630401

Gerlier, D., M.C. Trescol-Biemont, G. Varior-Krishnan, D. Naniche and I. Fugier-Vivier et al., 1994. Efficient MHC class II-restricted presentation of measles virus to $\mathrm{T}$ cells relies on its targeting to its cellular receptor human CD46 and involves an endosomal pathway. Cell Biol. Int., 18: 315-320. DOI: $10.1006 /$ cbir.1994.1080

Griffin, D.E. and M.B.A. Oldstone, 2008. Measles: History and Basic Biology. 1st Edn., Springer, Berlin Heidelberg, ISBN-10: 3540705228, pp: 200.

Grote, D., S.J. Russell, T.I. Cornu, R. Cattaneo and R. Vile et al., 2001. Live attenuated measles virus induces regression of human lymphoma xenografts in immunodeficient mice. Blood, 97: 3746-3754. DOI: 10.1182/blood.V97.12.3746

Hasegawa, K., C. Hu, T. Nakamura, J.D. Marks and S.J. Russell et al., 2007. Affinity thresholds for membrane fusion triggering by viral glycoproteins. J. Virol., 81: 13149-13157. DOI: 10.1128/JVI.01415-07

Kärber, G., 1931. Beitrag zur kollektiven Behandlung pharmakologischer Reihenversuche. Arch. Exp. Path. Pharmak., 162: 480-487. DOI: 10.1007/bf01863914

Katz, S.L., 2009. John F. Enders and measles virus vaccine-a reminiscence. Curr. Top Microbiol. Immunol., 329: 3-11. DOI: 10.1007/978-3-54070523-9 4

Katz, S.L., M.V. Milovanovic and J.F. Enders, 1958. Propagation of measles virus in cultures of chick embryo cells. Proc. Soc. Exp. Biol. Med., 97: 23-29. DOI: $10.3181 / 00379727-97-23637$

Kohn, A. and D. Yassky, 1962, Growth of measles virus in KB cells. Virology, 17: 157-163. DOI: 10.1016/0042-6822(62)90092-2

Kohn, A., 1962, Haemadsorption by measles syncytia. Nature, 193: 1088-1089. DOI: 10.1038/1931088a0

Langfield, K.K., H.J. Walker, L.C. Gregory and M.J. Federspiel, 2011. Manufacture of measles viruses. Methods Mol Biol, 737: 345-366. DOI: 10.1007/978-1-61779-095-9 14

Leber, M.F., S. Bossow, V.H. Leonard, K. Zaoui and C. Grossardt et al., 2011. MicroRNA-sensitive oncolytic measles viruses for cancer-specific vector tropism. Mol. Ther., 19: 1097-1106. PMID: 21468006

Matumoto, M., 1966. Multiplication of measles virus in cell cultures. Bacteriol Rev, 30: 152-176.

Mayer, E.D., 1960. Plaque formation by measles virus. Virology, 11: 634-638.
Mendonca, R.Z., L.R. Vaz-de-Lima, M.I. Oliveira, C.A. Pereira and S. Hoshino-Shimizu, 1994. Studies on the efficiency of measles virus antigen production using VERO cell culture in a microcarrier system. Braz J. Med. Biol. Res., 27: 1575-1587. PMID: 7874024

Mendonca, R.Z., S.J. Arrozio, M.M. Antoniazzi, J.M.J. Ferreira and C.A. Pereira, 2002. Metabolic active-high density VERO cell cultures on microcarriers following apoptosis prevention by galactose/glutamine feeding. J. Biotechnol., 97: 1322. DOI: 10.1016/S0168-1656(02)00048-2

Milovanovic, M.V., J.F. Enders and A. Mitus, 1957. Cultivation of measles virus in human amnion cells and in developing chick embryo. Exp. Biol. Med., 95: 120-127. DOI: 10.3181/00379727-95-23140

Morgan, E.M. and F. Rapp, 1977. Measles virus and its associated diseases. Bacteriol. Rev., 41: 636-666.

Msaouel, P., A. Dispenzieri and E. Galanis, 2009a. Clinical testing of engineered oncolytic measles virus strains in the treatment of cancer: an overview. Curr Opin. Mol. Ther., 11: 43-53.

Msaouel, P., I.D. Iankov, A. Dispenzieri and E. Galanis, 2011. Attenuated oncolytic measles virus strains as cancer therapeutics. Curr. Pharm. Biotechnol., DOI: BSP/CPB/E-Pub/000272-13-1

Msaouel, P., I.D. Iankov, C. Allen, J.C. Morris and von V. Messling et al., 2009b. Engineered measles virus as a novel oncolytic therapy against prostate cancer. Prostate, 69: 82-91. DOI: 10.1002/pros.20857

Mühlebach, M., M. Mateo, P. Sinn, S. Prufer and K. Uhlig et al., 2011. Adherens junction protein nectin4 (PVRL4) is the epithelial receptor for measles virus. Nature, 480: 530-533. DOI: 10.1038 /nature 10639

Mühlebach, M.D., T. Schaser, M. Zimmermann, S. Armeanu and K.M. Hanschmann et al., 2010. Liver cancer protease activity profiles support therapeutic options with matrix metalloproteinase-activatable oncolytic measles virus. Cancer Res., 70: 76207629. DOI: 10.1158/0008-5472.CAN-09-4650

Nakai, T., F.L. Shand and A.F. Howatson, 1969, Development of measles virus in vitro. Virology, 38 : 50-67. PMID: 4977468

Nakamura, T., K.W. Peng, M. Harvey, S. Greiner and I.A. Lorimer et al., 2005. Rescue and propagation of fully retargeted oncolytic measles viruses. Nat Biotechnol., 23: 209-214. DOI: 10.1038/nbt1060

Navaratnarajah, C.K., V.H. Leonard and R. Cattaneo, 2009. Measles virus glycoprotein complex assembly, receptor attachment, and cell entry. Curr. Top Microbiol. Immunol., 329: 59-76. DOI: 10.1007/978-3-540-70523-9_4 
Nehring, D., P. Czermak, J. Vorlop and H. Lubben, 2004. Experimental study of a ceramic microsparging aeration system in a pilot-scale animal cell culture. Biotechnol. Progress, 20: 17101717. DOI: $10.1021 / \mathrm{bp} 049762 \mathrm{e}$

Nehring, D., R. Gonzalez, R. Pörtner and P. Czermak, 2006. Experimental and modelling study of different process modes for retroviral production in a fixed bed reactor. J. Biotechnol., 122: 239-253. DOI: 10.1016/j.jbiotec.2005.09.014

Nehring, D., R. Pörtner, M. Schweizer, K. Cichutek and P. Czermak, 2009. Integrated in line filtration: A method to produce high concentrated retroviral vector titer supernatant. Desalination, 246: 241-247. DOI: $10.1016 / \mathrm{j}$.desal.0000.00.000

Noyce, R.S., D.G. Bondre, M.N. Ha, L.T. Lin and G. Sisson et al., 2011. Tumor cell marker PVRL4 (Nectin 4) is an epithelial cell receptor for measles virus. Plos. Pathog., 7: e1002240-e1002240. PMID: 21901103

Peebles, T.C., K. McCarthy, J.F. Enders and A. Holloway, 1957. Behavior of monkeys after inoculation of virus derived from patients with measles and propagated in tissue culture together with observations on spontaneous infections of these animals by an agent exhibiting similar antigenic properties. J. Immunol., 78: 63-74. PMID: 13406267

Peng, K.W., C.J. TenEyck, E. Galanis, K.R. Kalli and L.C. Hartmann et al., 2002. Intraperitoneal therapy of ovarian cancer using an engineered measles virus. Cancer Res., 62: 4656-4662. PMID: 12183422

Rapp, F., 1964. Plaque differentiation and replication of virulent and attenuated strains of measles virus. J. Bacteriol., 88: 1448-1458.

Rapp, F., J.S. Butel and C. Wallis, 1965. Protection of measles virus by sulfate ions against thermal inactivation. J. Bacteriol., 90: 132-135.

Reed, L.J. and H. Muench, 1938. A simple method of estimating fifty percent endpoint dilution. Am. J. Epidemiol., 27: 493-497.

Reissig, M., F.L. Black and J.L. Melnick, 1956. Formation of multinucleated giant cells in measles virus infected cultures deprived of glutamine. Virology, 2: 836-838. PMID: 13392528

Romano, N. and G. Scarlata, 1973. Amino acids requirements of measles virus in HeLa cells. Arch Gesamte Virusforsch, 43: 359-366. DOI: 10.1007/BF01556153

Rourou, S., A.V.D. Ark, T.V.D. Velden and H. Kallel, 2007. A microcarrier cell culture process for propagating rabies virus in Vero cells grown in a stirred bioreactor under fully animal component free conditions. Vaccine, 25: 3879-3889. DOI: 10.1016/j.vaccine.2007.01.086
Russell, S.J., A.K. Fielding, K.W. Peng and D. Grote, 2010. Method for limiting the growth of cancer cells using an attenuated measles virus. Mayo Foundation for Medical Education and Research.

Sabella, C., 2010. Measles: Not just a childhood rash. Cleve Clin. J. Med., 77: 207-213. PMID: 20200172 DOI: $10.3949 /$ ccjm.77a.09123

Scheld, W.M., R.J. Whitley and C.M. Marra, 2004. Infections of the Central Nervous System. 3rd Edn., Lippincott Williams and Wilkins, Philadelphia, ISBN-10: 0781743273, pp: 939.

Scott, J.V. and P.W. Choppin, 1982. Enhanced yields of measles virus from cultured cells. J. Virol. Methods, 5: 173-179. DOI: 0166-0934(82)90007-6

Shishido, A., K. Yamanouchi, M. Hikita, T. Sato, A. Fukuda and F. Kobune, 1967. Development of a cell culture system susceptible to measles, canine distemper and rinderpest viruses. Arch. Virol., 22: 364-380. DOI: 10.1007/BF01242957

Sidorenko, E.S., L.V. Dorofeeva, T.I. Kaptsova, L.L. Steinberg and I.N. Zasorina et al., 1989. Experimental-scale measles and mumps vaccine production on microcarrier-grown cells. Vaccine, 7: 554-556. DOI: 10.1016/0264-410X(89)90282-X

Springfeld, C., V. von Messling, M. Frenzke, G. Ungerechts and C.J. Buchholz et al., 2006. Oncolytic efficacy and enhanced safety of measles virus activated by tumor-secreted matrix metalloproteinases. Cancer Res., 66: 7694-7700. DOI: 10.1158/0008-5472.CAN-06-0538

Tatsuo, H., N. Ono, K. Tanaka and Y. Yanagi, 2000. SLAM (CDw150) is a cellular receptor for measles virus. Nature, 406: 893-897. DOI: $10.1038 / 35022579$

Trabelsi, K., S. Majoul, F. Charfi and H. Kallel, 2010. Measles virus production in MRC-5 cells grown on microcarrier in a stirred bioreactor. ESACT Proc., 4: 765-769. DOI: 10.1007/978-90-481-3419-9 133

Trabelsi, K., S. Majoul, S. Rourou and H. Kallel, 2012. Development of a measles vaccine production process in MRC-5 cells grown on Cytodex 1 microcarriers and in a stirred bioreactor. Applied Microbiol. Biotechnol., 93: 1031-1040. DOI: 10.1007/s00253-011-3574-y

Udem, S.A., 1984. Measles virus: Conditions for the propagation and purification of infectious virus in high yield. J. Virol. Methods, 8: 123-136. DOI: 10.1016/0166-0934(84)90046-6

Wechsler, S.L., D.M. Lambert, M.S. Galinski, B.E. Heineke and A.L. Lambert et al., 1985. A Simple method for increased recovery of purified paramyxovirus virions. J. Virol. Methods, 12: 179182. DOI: 10.1016/0166-0934(85)90018-7 